\title{
Changes in the soil microbial communities of different soil aggregations after vegetation restoration in a semiarid grassland, China
}

\author{
Zhijing Xue ${ }^{1}$, Zhengchao Zhou ${ }^{1}$, Shaoshan $\mathrm{An}^{2, *}$ \\ 1 School of Geography and Tourism, Shaanxi Normal University, Xi'an 710119, China \\ 2 State Key Laboratory of Soil Erosion and Dryland Farming on Loess Plateau, Northwest A\&F University, Yangling 712100, China
}

H I G H L I G H T S

- The soil aggregate stability increased with increasing duration of vegetation restoration. - Natural restoration has a positve effect on soil microbial diversity that was generally higher in large particle size aggregates, which leads to low environmental stress and strong stability.

- Microorganism continually changed their regulation of metabolism pathways as their environment changed.

- Environment adaptability influences soil physiological indicators to varying degrees.

- After years of natural restoration, the soil microbial community generally transformed from nutrient-rich to heterotroph-dominan.

\section{ARTICLE INFO}

Article history:

Received May 14, 2020

Revised July 9, 2020

Accepted July 29, 2020

Keywords:

Vegetation restoration

Plant succession

Phospholipid fatty acid (PLFA)

Soil aggregate fractions

Soil microorganism group
GRAPHICAL ABSTRACT

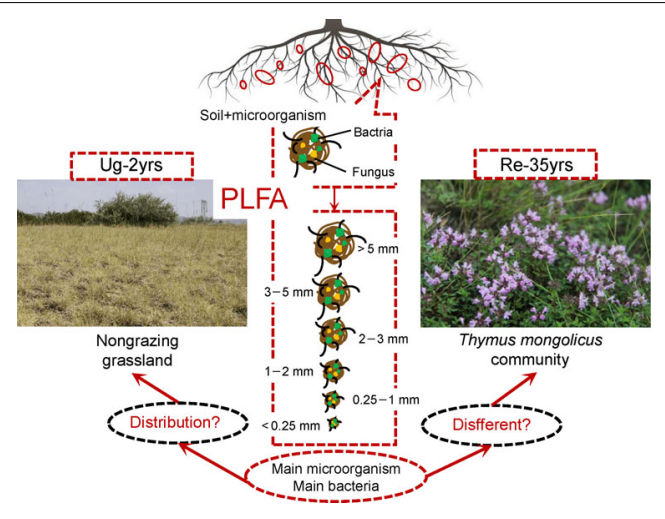

A B S TR A C T

Soil aggregate fractions can regulate microbial community composition and structure after vegetation restoration. However, there has been less focus on the effects of soil aggregate fractions on the distributions of microbial communities. Here, we used phospholipid fatty acid (PLFA) analysis to explore the effects of different years of vegetation restoration (a 35-year-old Thymus mongolicus community (Re-35yrs) and a 2-year-old nongrazing grassland (Ug-2yrs)) on microbial communities within different soil aggregate sizes ( $<0.25 \mathrm{~mm}, 0.25-1 \mathrm{~mm}, 1-2 \mathrm{~mm}, 2-3 \mathrm{~mm}, 3-5 \mathrm{~mm}$ and $>5 \mathrm{~mm}$ ). The results indicated that the amount of total PLFA in Re-35yrs was 10 times greater than that in Ug$2 \mathrm{yrs}$. The soil aggregate stability increased with increasing duration of vegetation restoration. In Re35yrs, the total PLFA shown an increase as the soil aggregate size increased, and the highest values were observed in 3-5 mm. Ug-2yrs differed from Re-35yrs, the soil microbial diversity was higher in medium particle sizes $(1-2 \mathrm{~mm}$ and $2-3 \mathrm{~mm})$ and lower in microaggregates $(<0.25 \mathrm{~mm}$ and 0.25 $1 \mathrm{~mm}$ ) and macroaggregates $(3-5 \mathrm{~mm}$ and $>5 \mathrm{~mm}$ ). Soil microbial diversity was highest in large particle size aggregates, which resulted in low environmental stress and strong stability. The same tendency was observed in the high values of cyc/prec, S/M and soil organic matter, which indicated a lower turnover speed (F/B) of fungal energy utilization and a higher fixation rate. After years of natural restoration, the soil microbial community generally transformed from nutrient-rich to heterotrophdominant, especially in microaggregates (reflected in the $\mathrm{G}^{+} / \mathrm{G}^{-}$ratio).

(c) Higher Education Press 2020

\footnotetext{
* Corresponding author

E-mail address: shan@ms.iswc.ac.cn (S. An)
}

\section{Introduction}

Grasslands are among the largest ecosystems in the world. Grassland enclosure promotes vegetation succession and is 
one of the strategies used to control land degradation (Liu et al., 2008; Lenka et al., 2012; Deng et al., 2018); in addition, enclosure is considered to be an effective and economical practice for restoring plant and soil communities (Walker et al., 2007; Herrera et al., 2016; Zhao et al., 2019). A growing body of ecological research on the plant-microbe interactions in soil during the restoration of plant diversity and under management practices have been a major focus of research (Fanin et al., 2016; Deng and Shangguan, 2017; Zhu et al., 2019). The changes in microbial community composition that occur during succession are closely related to changes in ecosystem function ( $\mathrm{Li}$ et al., 2018; Liu et al., 2020a; Zhao et al., 2019). Understanding the changes in the characteristics of the microbial community structure that occur throughout ecological succession could elucidate the mechanisms that drive successional dynamics, especially considering that less is known about the belowground microbial community and how it changes with long-term succession in an ecosystem (Liu et al., 2020b). Previous studies have reported that positive and negative feedback between plants and soil microbes play central roles in early and late successional communities ( $\mathrm{Li}$ et al., 2018; Wang et al., 2019; Guo et al., 2019; Zhao et al., 2019). However, how the microbial community and soil properties collaboratively develop during the middle stages of succession remains unclear.

Microbial community structure is closely related to the living environment in soil (Cao et al., 2017). Soils, with their nonuniform distribution of microenvironment conditions and nutrients across different aggregate-size fractions, provide spatially heterogeneous habitats for microorganisms, which are characterized by differences in resource availability, moisture content, oxygen concentration and predation pressure (Ranjard and Richaume, 2001; Muruganandam et al., 2010; Vos et al., 2013; Jiang et al., 2017; Liao et al., 2018). Moreover, few studies have simultaneously focused on the soil microbial communities across the different aggregate size fractions that are associated with biologically and biochemically mediated transformations of soil nutrients (Smith et al., 2014; Trivedi et al., 2017). Furthermore, it remains unclear whether changes in the aggregate size of the microbial community structure can promote or hinder stability once plant communities develop to the climax community stage. Studies on the composition and function of belowground microbial communities have thus far only been conducted on soil nutrient cycling and organic matter formation and decomposition (Trivedi et al., 2013, 2017). During vegetation succession, large changes occur in the soil aggregate stability, leading to the hypothesis that these changes should also affect the structure of the soil microbial community (An et al., 2013; Liu et al., 2013; Yan et al., 2020; Xiao et al., 2020). Macroaggregates $(2000-2500 \mu \mathrm{m})$ generally contain more labile substrates than substrates that are predominantly derived from plant residues and exhibit a higher fungal biomass than microaggregates (Jiang et al., 2017). In contrast, microaggregates provide a protective microenvironment for microbial growth and stable SOC (soil organic carbon) (Six et al., 2000).
However, we do not understand how aggregate fractions regulate microbial community composition and structure as vegetation composition changes, especially in the middle stages of succession.

The current study was conducted on Yunwu Mountain, a semiarid grassland in the Loess Plateau. This well-documented site represents 40 years of long-term fencing and has a good sequence of undisturbed secondary succession. Thus, this area offers a unique sequence to investigate characteristics of microbial communities. Here, we selected a dominant species (Thymus mongolicus community) in the middle of the succession to investigate the soil microbial physiological indicators that are associated with different aggregate size and restoration years. Specifically, the primary aim of this study was to compare the difference in the soil microbial community composition and structure in a 35-year-old Thymus mongolicus community (Re-35yrs) and 2-year-old nongrazing grassland (Ug-2yrs). In this study, we addressed the following hypotheses: (1) soil microbial diversity increases with vegetation restoration years; (2) the aggregate-related changes in soil microbial communities, soil microbial diversity and stability are mainly driven by aggregate-size fractions.

\section{Materials and methods}

\subsection{Study area and methods}

The study area was located in the Yunwu Mountain Reserve for Vegetation Protection and the Eco-environment, Guyuan City, Ningxia Autonomous Region, between $106^{\circ} 24^{\prime} \mathrm{E}$ and $106^{\circ} 28^{\prime} \mathrm{E}$ longitude and between $36^{\circ} 13^{\prime} \mathrm{N}$ and $36^{\circ} 19^{\prime} \mathrm{N}$ latitude, China. Grassland is the native vegetation in this region. After more than 30 years of restoration since the observatory was established in 1982, the vegetation in the protected area belongs to two types: grassland and brush. The reserve includes three areas, namely, a core area, a buffer area and an experimental area, which have relatively similar geographical patterns and climate (Fig. 1). The reserve has a semiarid temperate continental monsoon climate. The mean annual total sunshine hours, annual evaporation and average forest-free days per year were $2518 \mathrm{~h}, 1600 \mathrm{~mm}$, and 137 days, respectively (Deng et al., 2014). The average annual temperature and precipitation were $8^{\circ} \mathrm{C}$ and $371 \mathrm{~mm}$ (1991-2015), and 70\% rainfall occurred between June and September. The soil types in the experimental site are Loessial soils (Chinese Soil Classification) (Shi et al., 2010) and Entisols (USA taxonomy) (Soil Survey Staff, 2010).

After 20 years of enclosure management, plant communities have formed in different succession stages. The area includes 5 subtypes, 11 formations and more than 40 associations, with classical grasslands being the primary biome. The primary plant species are herbaceous plants (i.e., Androsace erecta, Artemisia capillaries, Artemisia frigid, Artemisia sacrorum, Heteropappus altaicus, Potentilla acaulis, Stipa bungeana, Stipa grandis, Thymus monoglicus, etc.). 


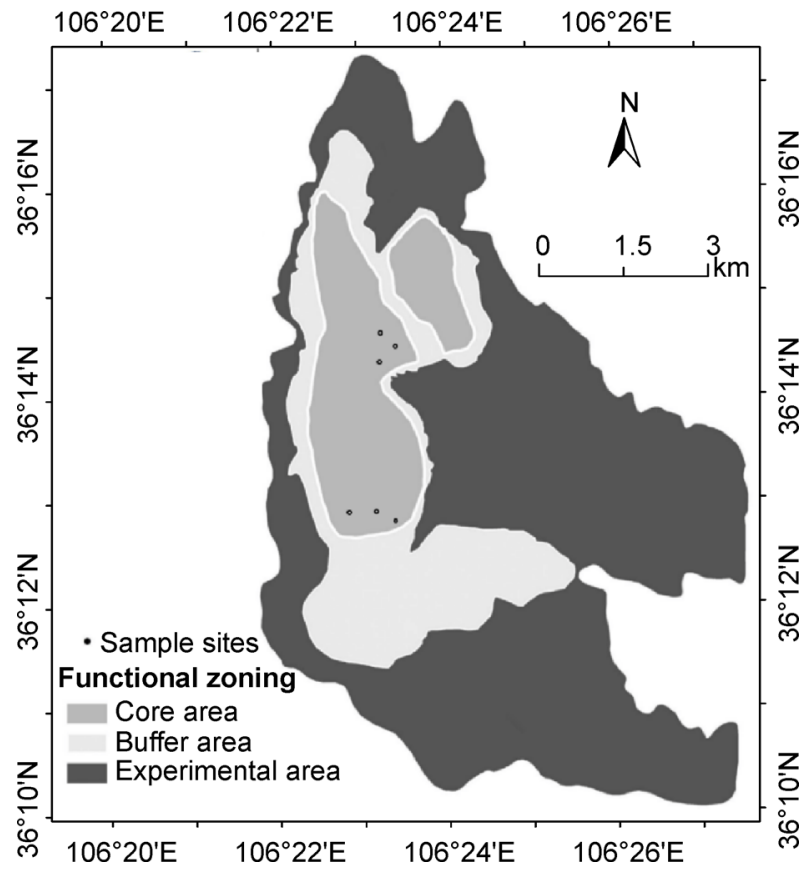

Fig. 1 The location of study area.

From the early 1980 s to the 1990s, a group of scholars including Zou and Guan (1997) conducted detailed studies and summaries of the vegetation succession and defined the stages and characteristics of the vegetation succession of abandoned farmland and grazing land after the removal of disturbance factors, such as tillage and grazing. The core area comprises approximately 1000 ha, which accounts for $25 \%$ of the total area. In the core area, Stipa bungeana is the most extensive; the dominant grass species are Stipa grandis and Stipa bungeana, and the dominant forb species are Thymus mongolicus and Artemisia sacrorum.

When the grazing is ended, the succession of Stipa bungeana grassland with different degrees of degradation will start again from each retrograde degradation stage, and the whole succession process will be driven by the fierce competition between the species. Although Thymus mongolicus does not become the main auxiliary species of zonal vegetation and the vegetation climax community in the natural succession process, it appears to be the dominant species in degraded grassland and plays an important role in the succession process. When a Stipa bungeana community is degraded to a Thymus mongolicus community, it needs approximately 14 years (shady slope) to 19 years (sunny slope) to be restored to a Stipa bungeana community. This relatively long succession process is shown in Fig. 2 and occurs in the following sequence: Thymus mongolicus (5-7 years, Stipa bungeana occupying the bare space)-Thymus mongolicus + Stipa bungeana (6-8 years, Stipa bungeana recovery stage)-Stipa bungeana + weed plants (3-4 years, Stipa bungeana recovery stage)-Stipa bungeana community (Zou and Guan, 1997). Therefore, we chose to study a Thymus mongolicus community, which is very important in the succession process, and compared it to degraded grassland with 2 years nongrazing in order to study the role of a Thymus mongolicus community in the succession sequence. In particular, the 2 years grassland is a degraded Stipa bungeana community.

\subsection{Sample collection}

The soil samples were obtained duringAugust 2016 from the core area when the biomass had reached its peak. Three replicate $20 \mathrm{~m} \times 20 \mathrm{~m}$ plots were established for each site, in total there were 9 plots (Fig. 3). These Re-35yrs and Ug-2yrs plots were selected for similar latitude, longitude, elevation, slope aspect, and slope gradient (Table 1). The distance between the sampling plots within each sampling site was not less than $20 \mathrm{~m}$. Three $1 \mathrm{~m}^{2}$ quadrats were randomly established across each plot to assess heterogeneity. Undisturbed soil was collected simultaneously using a $5-\mathrm{cm}$ diameter soil auger and composited. The soil samples were obtained from $0-20 \mathrm{~cm}$ and $20-40 \mathrm{~cm}$ depths. Soil was layered and stored in sterilized plastic containers for aggregate fraction. The soil samples were placed on ice for transport to the laboratory.

In the laboratory, the undisturbed soil samples were gently broken up along natural fractures and passed through an $8 \mathrm{~mm}$ sieve after removing the large roots and stones. The prepared soil samples were fractionated using a dry-sieving method that was used to separate soil fractions to minimize the effects of wet-sieving method on microbial communities and produce aggregate fractions along nautral points of weakness (Jiang et al., 2017). The fresh soil samples (150 g) were sieved through a series of meshes, $>5 \mathrm{~mm}, 5-3 \mathrm{~mm}, 3-$ $2 \mathrm{~mm}, 2-1 \mathrm{~mm}, 1-0.25 \mathrm{~mm}$ and $<0.25 \mathrm{~mm}$, by shaking at $250 \mathrm{r} \mathrm{min}^{-1}$ for $3 \mathrm{~min}$. The prepared soil samples stored at $-80^{\circ} \mathrm{C}$ were used for determining PLFA content.

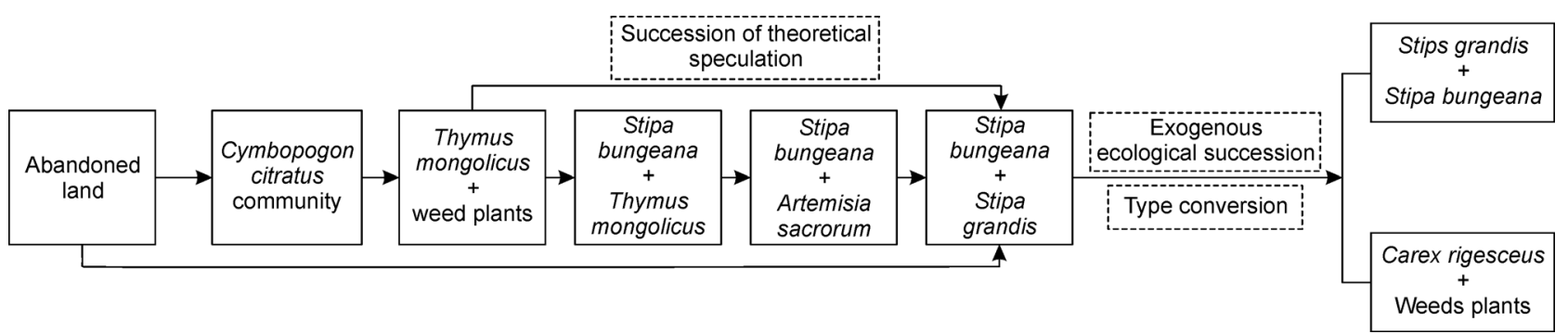

Fig. 2 The evolvement of uncultural land natural rehabilitation in Yun-wu wilderness area. 


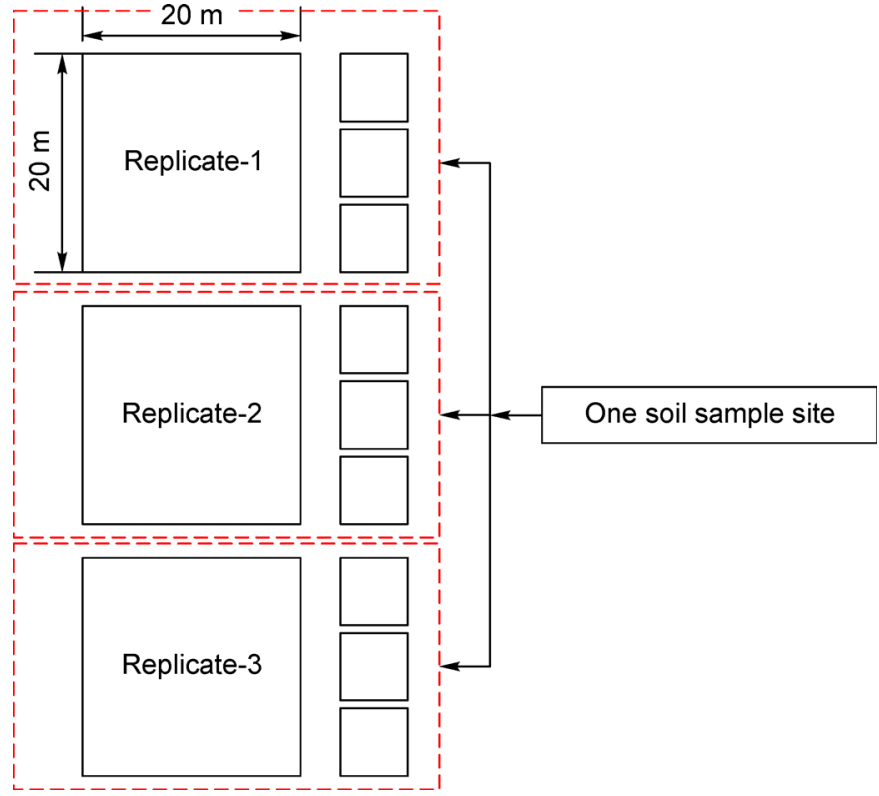

Fig. 3 Setup of soil collection in each site

\subsection{Laboratory analysis}

Microbial community structure was measured by PLFA analysis based on the procedures described by Bardgett and McAlister (1999), which was further described by Pollierer et al. (2015), with modification. Phospholipid fatty acid (PLFA) is a biomarker that can be extracted from cell membranes synthesized by various biochemical pathways and quantitatively reflects the total biomass of diverse microbial groups. Due the fact that PLFA breaks down quickly upon cell death, it also reflects microbial biomass due to organisms with high prolificacy (Janine et al., 2005). An external standard of 19:0 methyl ester was used for quantification (Frostegård et al., 1993), and the amount of PLFA was expressed as nmol g ${ }^{-1}$ of dry soil. Briefly, fatty acids were extracted from $3.0 \mathrm{~g}$ of freezedried soil using a solution containing citrate buffer, chloroform, and methanol. The PLFAs were separated from neutral and glycolipid fatty acids by solid-phase-extraction chromatography. After mild alkaline methanolysis, the PLFAs were analyzed using a gas chromatograph (GC7890A, Agilent Technologies Inc., Wilmington, USA) equipped with MIDI
Sherlock software (version 4.5; MIDI Inc., Newark, USA).

The sum of all the biomarkers was used as a proxy for the total microbial biomass (total PLFAs). The saturated fatty acid 16:0 exists widely in various groups and is often used to evaluate the total microbial biomass. Zelles (1999) reported that specific PLFA signatures can serve as indicators of specific microbial groups. Total PLFAs were obtained by adding the contents of all fatty acids detected in each sample. The PLFAs, including i13:0, a13:0, i14:0, etc., were selected to represent Gram-positive bacteria, while the PLFAs 14:1, cy19:0, etc. were grouped as representative of Gram-negative bacteria. Cyclopropyl branched chain PLFAs (PLFA cy17:0 and cy19:0) come only from bacteria, especially anaerobic species. Therefore, the concentration of PLFA can indicate the relative dominance of specific microbe groups (Luo et al., 2018; Liao et al., 2018). F/B ratio (ratio of fungal to bacterial biomass) and stress indicators [cy/pre ratio (ratio of cyclopropyl PLFAs (cy17:0 and cy19:0)) to precursors PLFAs (16:1w7c and 18:1w7c)]. The classification of the PLFAs is shown in Table 2.

Table 1 Description of soil sample site.

\begin{tabular}{llll}
\hline Soil sample site & Site No. & Altitude $(\mathrm{m})$ & Dominant species \\
\hline Thymus mongolicus community & 1 & 2024 & Thymus mongolicus; Leymus secalinus; Artemisia \\
& 2 & 2045 & scoparia; Stipa bungeana \\
Nongrazing grassland & 3 & 2077 & \\
& 4 & 1987 & Stipa bungeana; Artemisia sacrorum; Potentilla \\
& 5 & 1972 & acaulis; Heteropapus altaicus \\
\hline
\end{tabular}


Table 2 Characterization of microbial phospholipid fatty acids ( PLFA).

\begin{tabular}{|c|c|}
\hline Microbial group & Specific PLFA markers \\
\hline Fungi & $18: 1 \omega 9 c, 18: 2 \omega 6,9,18: 1 \omega 9 t$ \\
\hline Bacteria in general & 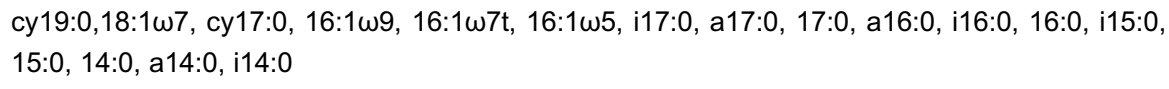 \\
\hline Aerobes & $16: 1 \omega 9,16: 1 \omega 7,16: 1 \omega 7 \mathrm{t}$ \\
\hline Anaerobes & cy19:0, сy17:0, \\
\hline Gram-positive bacteria & a17:0, i16:0, a16:0, i15:0, a15:0, a14:0, i14:0, \\
\hline Gram-negative bacteria & 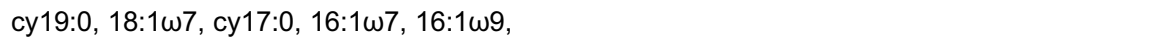 \\
\hline Methane-oxidizing bacteria & $18: 1 \omega 8 c, 16: 1 \omega 5 c$ \\
\hline Actinomycetes & 10Me18:0, 10Me17:0, 10Me16:0, \\
\hline Protozoa & $20: 4 \omega 6$ \\
\hline cy/pre ratio & $($ cy $17: 0+$ cy $19: 0) /(16: 1 \omega 7+18: 1 \omega 7)$ \\
\hline $\mathrm{S} / \mathrm{M}$ ratio & $\begin{array}{l}\text { Saturated/Monosaturated } \\
(20: 0,18: 0,17: 0,16: 0,15: 0,14: 0) /(18: 1 \omega 9 t, 18: 1 \omega 9 c, 18: 1 \omega 8 c, 18: 1 \omega 7,17: 1 \omega 8 c, 16: 1 \omega 9, \\
16: 1 \omega 7,16: 1 \omega 7 t, 16: 1 \omega 5,16: 1 \omega 5 c)\end{array}$ \\
\hline $\mathrm{G}^{+} / \mathrm{G}^{-}$ratio & Gram-positive bacteria/Gram-negative bacteria \\
\hline F/B ratio & Fungi/bacteria \\
\hline
\end{tabular}

(Kroppenstedt, 1985; Federle et al., 1986; O'Leary, 1988; Wilkinson, 1988; Zelles et al., 1995; Frostegård and Bååth, 1996; Ringelberg et al., 1997; Kieft et al., 1997; Bossio et al., 1998)

\subsection{Statistical analysis}

Variety statistical analyses were performed using SPSS 20.0 (SPSS Inc., Chicago, USA), to identify the effects of the successional grassland restoration on total PLFA, main microorganism, main bacteria, $\mathrm{G}^{+} / \mathrm{G}^{-}$ratio, $\mathrm{F} / \mathrm{B}$ ratio and cy/pre ratio. One-way analysis of variance (ANOVA) with restoration years and soil aggregate sizes as the main factors were employed to test the significance of the mean differences. The level set for a significant difference was $p<0.05$. A univariate procedure was used to examine the normality of the distribution of the observed data before conducting the ANOVA analysis. When the ANOVA test indicated a significant effect at $p<0.05$, the means of each soil variable for each classification factor were assessed using the multiple-mean comparison that was assessed using the Benjamini False Discovery Ratio method. The graphs were plotted using Sigmaplot 12.5 (Systat Software, San Jose, USA). PCA (principal component analysis) was used to analyze the differences in the PLFA composition between soil aggregate size and plant restoration years.

\section{Results}

\subsection{Aggregate sizes distribution}

The distribution of soil aggregate sizes in Re-35yrs and Ug2yrs were similar (Fig. 4). Aggregates with sizes of $0.25-1 \mathrm{~mm}$ were most common (33.25\%-Re-35yrs-0-20 cm, 36.19\%-Re-

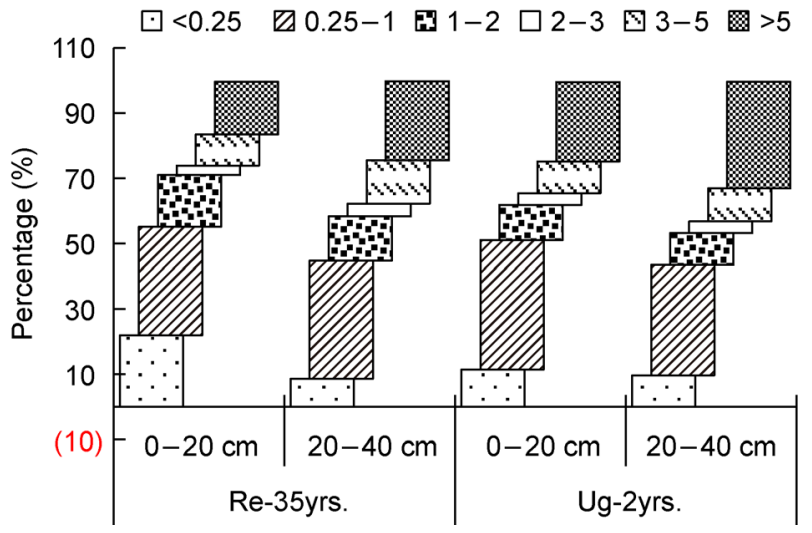

Fig. 4 Distribution characteristics of soil aggregate sizes' percentage.

35yrs-20-40 cm; 39.66\%-Ug-2yrs-0-20 cm and Ug-2yrs-20$40 \mathrm{~cm} 33.81 \%$ ). In order from the most to least prevalent sizes: $0.25-1>5>0.25>1-2>3-5>2-3 \mathrm{~mm}$.

\subsection{Soil organic carbon (SOC) and total nitrogen (TN)}

In Fig. 5, Re-35yrs had higher SOC concentrations that varied between 23.18 and $32.32 \mathrm{~g} \mathrm{~kg}^{-1}$, there has no significant differences between soil aggregate sizes. The SOC concentrations in Ug-2yrs ranged from 8.22 to $11.08 \mathrm{~g} \mathrm{~kg}^{-1}$, representing just one third that of Re-35yrs, and there was no consistent trend associated with soil depth. The SOC concentration for soil aggregate sizes $<0.25$ and $>5.00 \mathrm{~mm}$ 


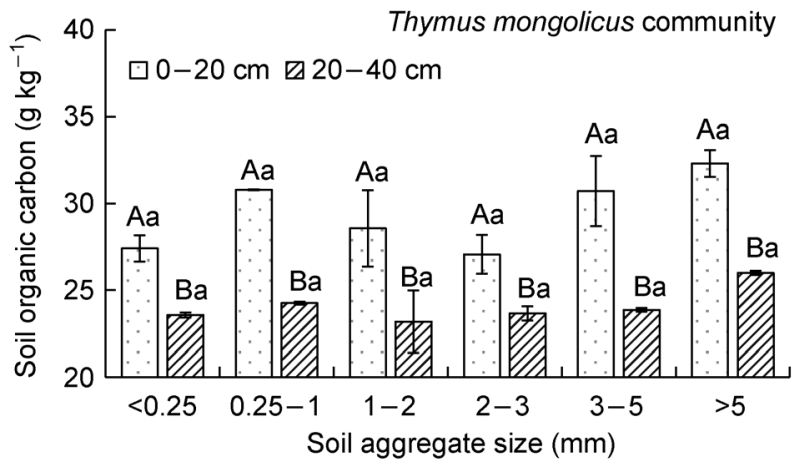

Fig. 5 Distribution characteristics of soil organic carbon.

were very different in the two soil depths.

As seen in Fig. 6, Re-35yrs had higher TN concentrations than $\mathrm{Ug}-2 \mathrm{yrs}$, with values between 2.68 and $3.38 \mathrm{~g} \mathrm{~kg}^{-1}$, and there was no significant difference between soil aggregate sizes. There was generally a downward trend in soil depth, except at the 2.00-3.00 mm aggregate size. However, the TN concentrations in Ug-2yrs were $0.79-1.35 \mathrm{~g} \mathrm{~kg}^{-1}$, which were just one third those of Re-35yrs. The concentrations were similar betweentwo soil depths, except for at the 0.25 $1.00 \mathrm{~mm}$ and $3.00-5.00 \mathrm{~mm}$.

\subsection{Total PLFA}

As seen in Fig. 7, Re-35yrs had higher total PLFA concentra-

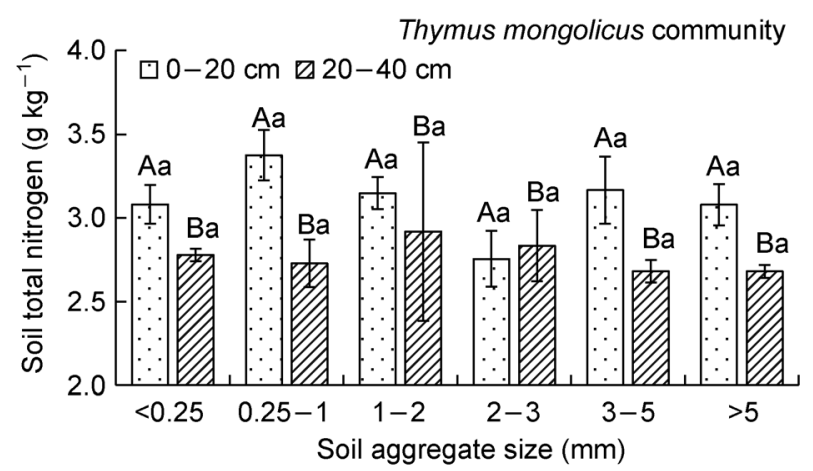

Fig. 6 Distribution characteristics of soil total nitrogen.

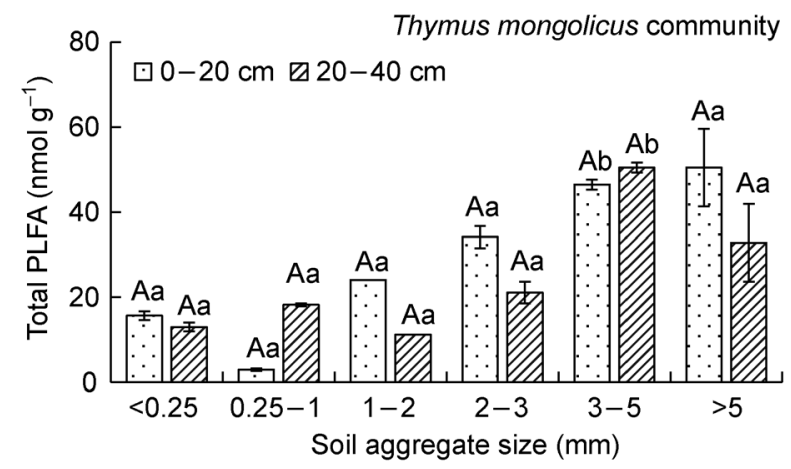

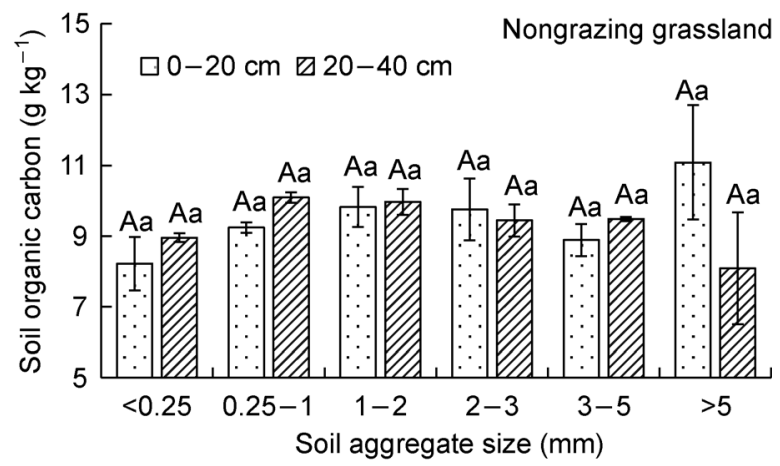

tions that varied between 2.93 and $50.49 \mathrm{nmol} \mathrm{g}^{-1}$. These concentrations were 1.48-9.77 times higher than those in Ug2yrs $\left(1.97-5.17 \mathrm{nmol} \mathrm{g}^{-1}\right)$. In the two communities, 3-5 mm and 1-2 $\mathrm{mm}$ had the highest concentrations among the different soil aggregates, respectively. There was generally downward trend in the PLFA concentration with soil depth, and the total PLFA decreased from topsoil $(0-20 \mathrm{~cm})$ to subsoil $(20-40 \mathrm{~cm})$. As soil aggregates increased, the total PLFA gradually decreased. In Re-35yrs, the PLFA concentrations in 2-3 and 3-5 mm were significantly increased, peaking in 3-5 $\mathrm{mm}$ aggregates before decreasing. However, in Ug$2 y r s$, there was a sharp upward trend in the 0.25-1 and 1$2 \mathrm{~mm}$ aggregates, with the highest value reached in the 1$2 \mathrm{~mm}$ aggregates, before gradually dwindling.
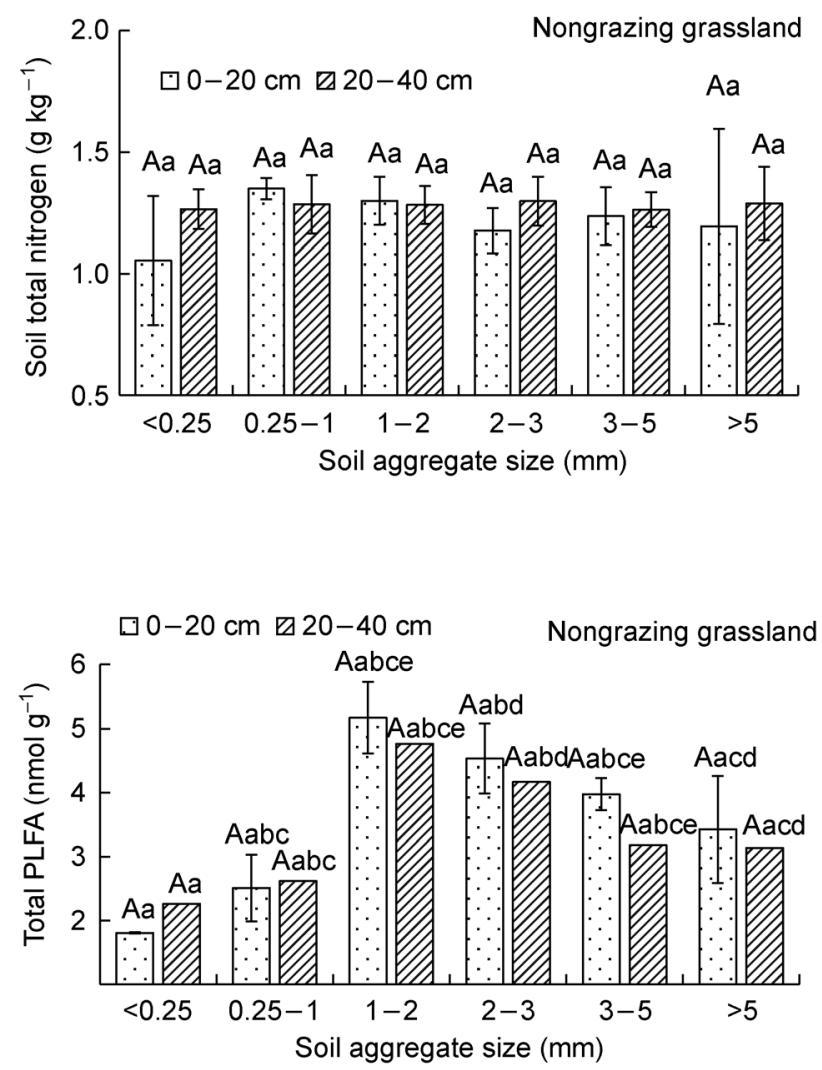

Fig. 7 The distribution characteristics of total PLFA in different soil aggregates. 


\subsection{Main microorganisms}

In Fig. 8, main microorganisms represent the highest proportion of bacterial concentration in both Re-35yrs (3.70$6.12 \mathrm{~mol} \%)$ and Ug-2yrs (2.42-7.44 mol\%). The proportions of unknown (Re-35yrs 0.19-4.15 mol\%), actinomycetes (Re35yrs 0.34-0.71 mol\%; Ug-2yrs 0.23-0.91 mol\%) and fungi (Re-35yrs 0.41-1.34 mol\%; Ug-2yrs 0.46-1.35 mol\%) followed, with protozoa representing the lowest proportion. Among the different soil aggregates, the proportion of bacteria in Re-35yrs was not obvious, except at 0.25-1 mm. However, the Ug-2yrs samples showed a significant upward trend, and the highest proportion of bacteria was observed in 1.00-2.00 $\mathrm{mm}$ aggregates, before gradually declining. The trends of actinomycetes and fungi were the same as those of bacteria, but the amplitudes were not obvious. Compared with the proportion of main microorganisms, the protozoa concentration was much lower, with no protozoa found in Re-35yrs (0$20 \mathrm{~cm})$ and Ug-2yrs $(20-40 \mathrm{~cm})$.

\subsection{Main bacteria}

In Fig. 9, the proportion of main bacteria in Re-35yrs $(0.17-$ $1.82 \mathrm{~mol} \%$ ) was higher than that in Ug-2yrs (0.24-2.44 mol\%). The proportion in the samples at $0-20 \mathrm{~cm}$ soil depth was higher than at $20-40 \mathrm{~cm}$. The proportion of main bacteria in $<0.25 \mathrm{~mm}$ and $>5.00 \mathrm{~mm}$ aggregates was lowest and increased in 3-5 mm, 1-2 mm and 2-3 mm aggregates, with the highest value reached in 1-2 mm aggregates. In Re-35yrs, Gram-positive bacteria had the highest values $(0-20 \mathrm{~cm}$ : 0.94-1.79 mol\% and 20-40 cm: 0.88-1.52 mol\%), with Gramnegative bacteria taking second place, followed by anaerobes and aerobes (anaerobes>aerobes), with the lowest being methane-oxidizing bacteria $(0-20 \mathrm{~cm}: 0.25-0.76 \mathrm{~mol} \%$ and $20-40 \mathrm{~cm}$ : 0.17-0.39 mol\%). However, in Ug-2yrs, Gramnegative bacteria represented the highest proportion of bacteria (0-20 cm: 0.88-2.78 mol\% and $20-40 \mathrm{~cm}: 1.07-$ 2.44 , mol\%), followed by Gram-positive bacteria and aerobes, with anaerobes and methane-oxidizing bacteria representing the lowest proportions $(0-20 \mathrm{~cm}: 0.24-0.74 \mathrm{~mol} \%$ and $20-$ $40 \mathrm{~cm}: 0.28-0.58 \mathrm{~mol} \%)$.

\subsection{Main physiologic indicators}

As shown in Table 3, the ratios of $\mathrm{G}^{+} / \mathrm{G}^{-}$in $\mathrm{Ug}-2 \mathrm{yrs}$ were significantly lower than in Re-35yrs. The ratios in Ug-2yrs were approximately 0.5 , while the values in Re-35yrs fell between 0.891 and 1.633 . In the $20-40 \mathrm{~cm}$ soil depth samples of Re-35yrs, the $\mathrm{G}^{+} / \mathrm{G}^{-}$ratios in the $<0.25 \mathrm{~mm}, 0.25-1.00 \mathrm{~mm}$, $1-2 \mathrm{~mm}$ aggregates were higher than those in the other soil aggregates. The F/B ratios were not significantly different between the 0-20 cm and $20-40 \mathrm{~cm}$ samples in Re-35yrs, and all the ratios had values of 0.17 . However, the F/B ratios in Ug2yrs decreased with increasing soil aggregate size, and the F/B ratios were 0.83 and 0.13 at different soil depths, respectively. The cy/pre ratios were greater at $0-20 \mathrm{~cm}$ soil depth than at $20-40 \mathrm{~cm}$, and the cy/pre ratios of the $20-40 \mathrm{~cm}$ soil depth samples in Ug-2yrs were higher than the other samples (0.54-0.65). The S/M ratios in Re-35yrs were significantly higher than in Ug-2yrs, and there was no significant difference between the two soil layers.

\subsection{Analysis of PLFA in different soil aggregate}

A discriminatory analysis of bacteria in different soil aggregates was conducted by identifying the contribution of bacterial PLFA concentrations to the principal components. Thus, the load was analyzed by principal component. If the load is large, the PLFA distribution of certain bacteria in soil aggregates can be considered to be wide (Table 4).

As Fig. 10 shows, in the $0-20 \mathrm{~cm}$ soil layer, the $1-2 \mathrm{~mm}$ and $<0.25 \mathrm{~mm}$ aggregates of Re-35yrs had the highest scores on the first principal component. The $3-5 \mathrm{~mm}$ and $2-3 \mathrm{~mm}$ aggregates had the highest scores on the second principal component. After composite score calculation, the 3-5 $\mathrm{mm}$ aggregates (2.00) had the highest score, followed by the 2 $3 \mathrm{~mm}$ aggregates (1.78), and the $>5 \mathrm{~mm}$ aggregates had the lowest score. Therefore, in the $0-20 \mathrm{~cm}$ soil layer, the first principal component represents the $3-5 \mathrm{~mm}$ and $2-3 \mathrm{~mm}$ aggregates, and the second principal component represents the $>5 \mathrm{~mm}$ aggregates. In the $20-40 \mathrm{~cm}$ soil layer, the $3-5 \mathrm{~mm}$ aggregates had the highest scores on the first principal component, and the $>5.00 \mathrm{~mm}$ aggregates had the highest scores on the second principal component. Thus, in the 20 $40 \mathrm{~cm}$ soil layer, the first principal component also represents the 3-5 $\mathrm{mm}$ and $2-3 \mathrm{~mm}$ aggregates, and the second principal component represents the $>5.00 \mathrm{~mm}$ and $2-3 \mathrm{~mm}$ aggregates. Thus, among the different soil aggregates of Re-35yrs, the 3-5 $\mathrm{mm}$ aggregates had a greater diversity than the other aggregate sizes, followed by the 2-3 $\mathrm{mm}$ and $>5 \mathrm{~mm}$ aggregates.

As Fig. 11 shows, in the layer of $0-20 \mathrm{~cm}$, the $1-2 \mathrm{~mm}$ and 2-3 $\mathrm{mm}$ aggregates of $\mathrm{Ug}-2 \mathrm{yrs}$ had the highest scores on the first principal component. The $3-5 \mathrm{~mm}$ aggregates had the highest score on the second principal component. After composite score calculation, the 1-2 $\mathrm{mm}$ aggregates (5.45) had the highest value, followed by the $2-3 \mathrm{~mm}$ aggregates (3.28), and the 3-5 mm aggregates (0.98) had the lowest value. Therefore, in the $0-20 \mathrm{~cm}$ soil layer, the first principal component represented the $3-5 \mathrm{~mm}$ and 2-3 $\mathrm{mm}$ aggregates and explained $85.86 \%$ of the variance. In the layer of 20 $40 \mathrm{~cm}$, the 1-2 and 2-3 $\mathrm{mm}$ aggregates had the highest scores on the first principal component. The 2-3 $\mathrm{mm}$ aggregates had the highest scores on the second principal component. After composite score calculation, the 1-2 mm aggregates had the highest value, followed by the $2-3 \mathrm{~mm}$ aggregates. In the other words, the first principal component represented the $1.00-2.00 \mathrm{~mm}$ and $2-3 \mathrm{~mm}$ aggregates and explained $78.56 \%$ of the variance. Thus, in different soil aggregates of Ug-2yrs, most soil microbes lived in the 1-2 and 2-3 $\mathrm{mm}$ aggregates. 


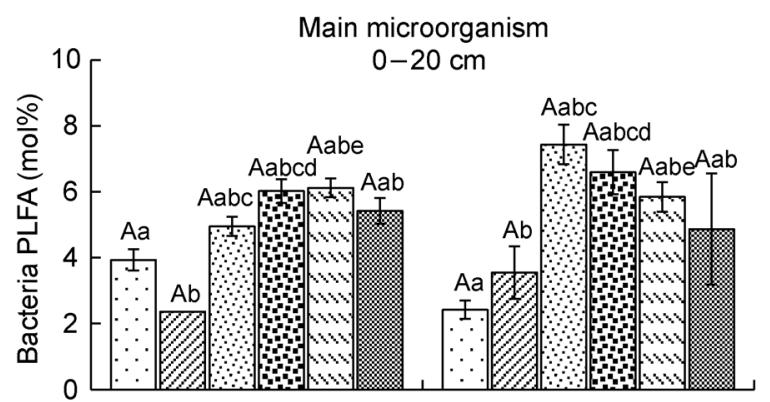

Re-35yrs.
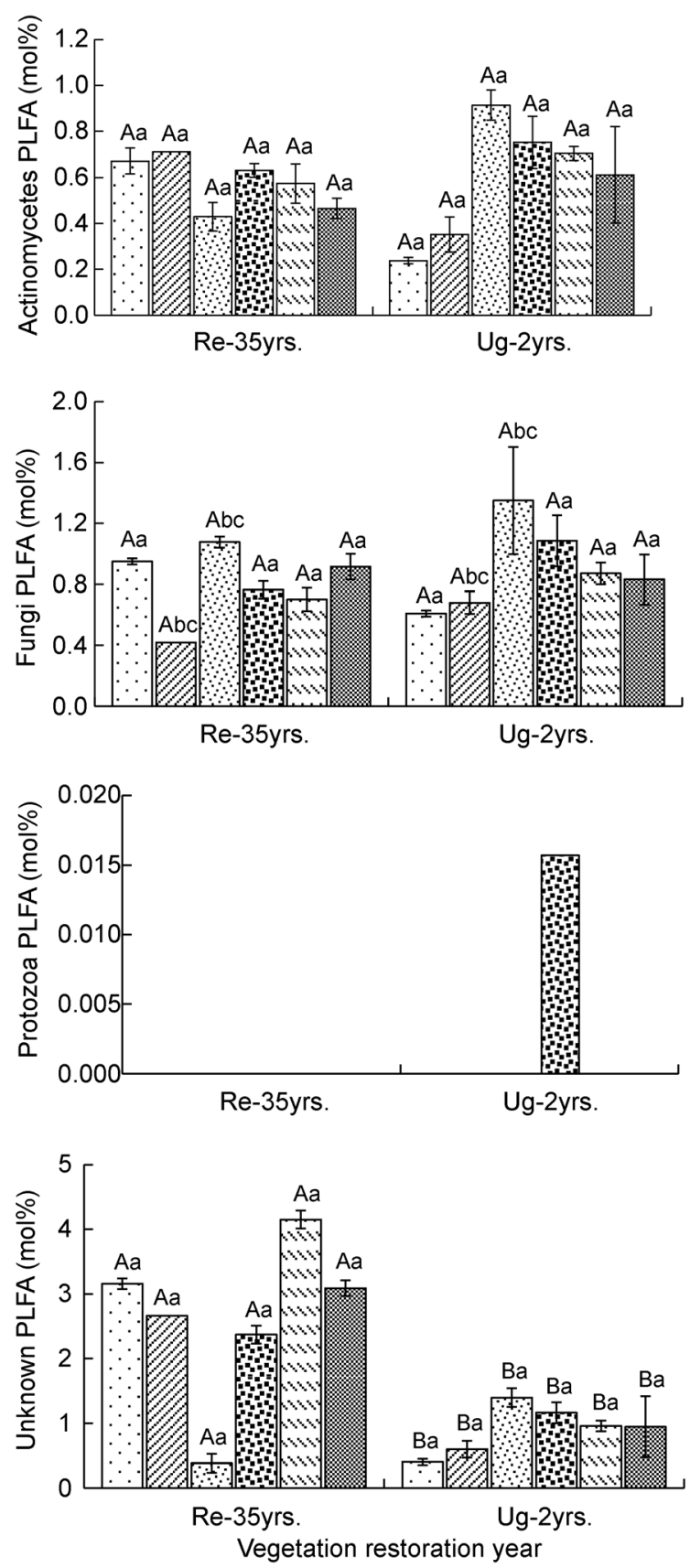

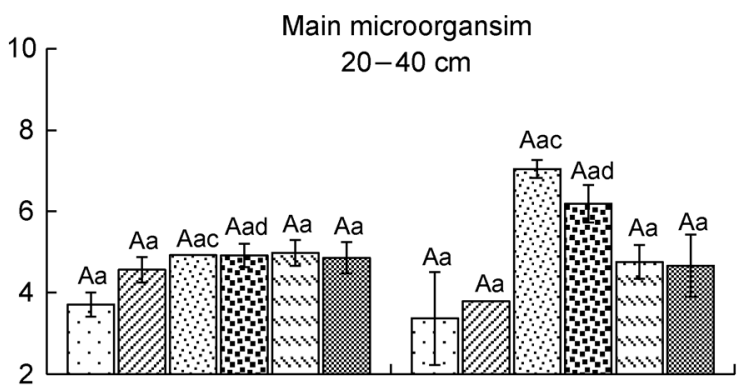

Re-35yrs.

Ug-2yrs.
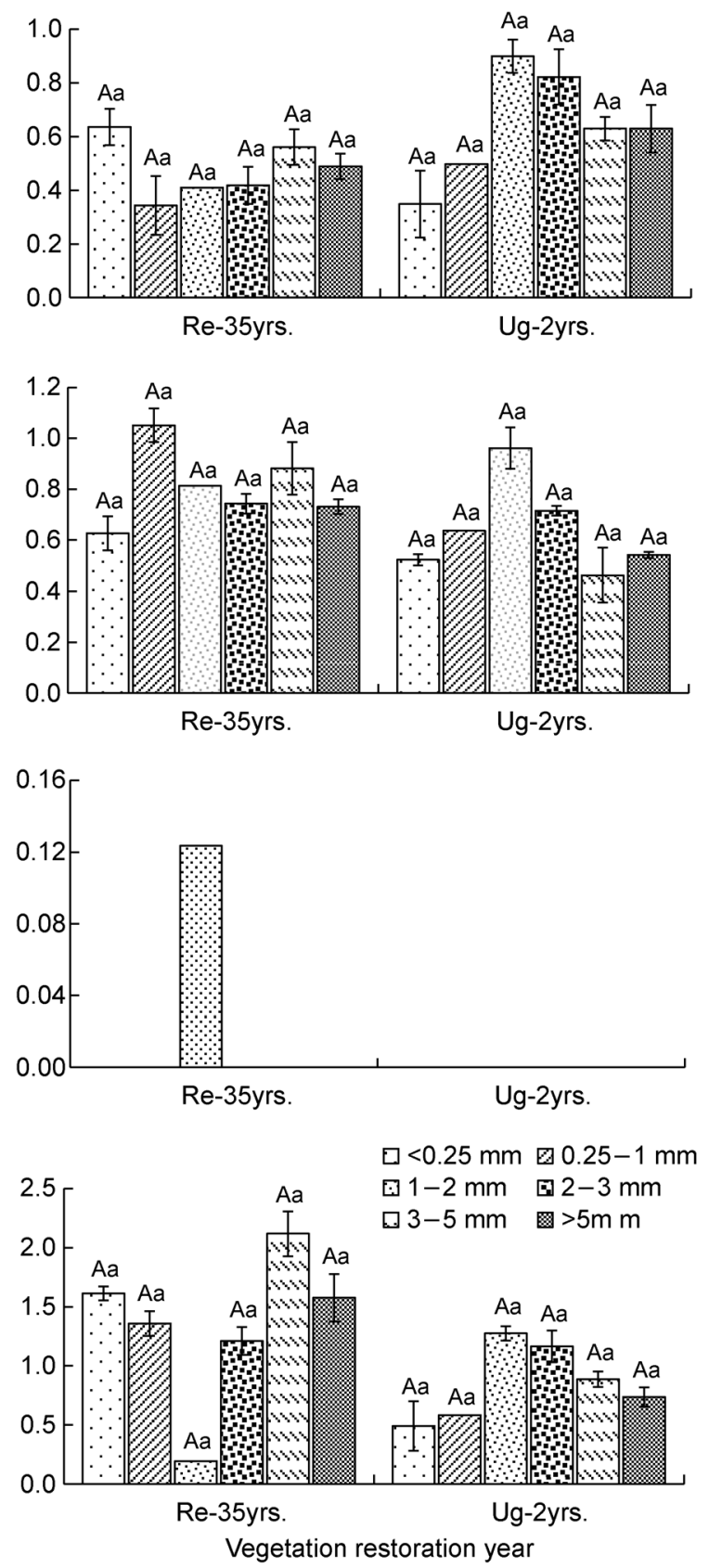

Fig. 8 The distribution characteristics of main microorganism in different soil aggregates. 

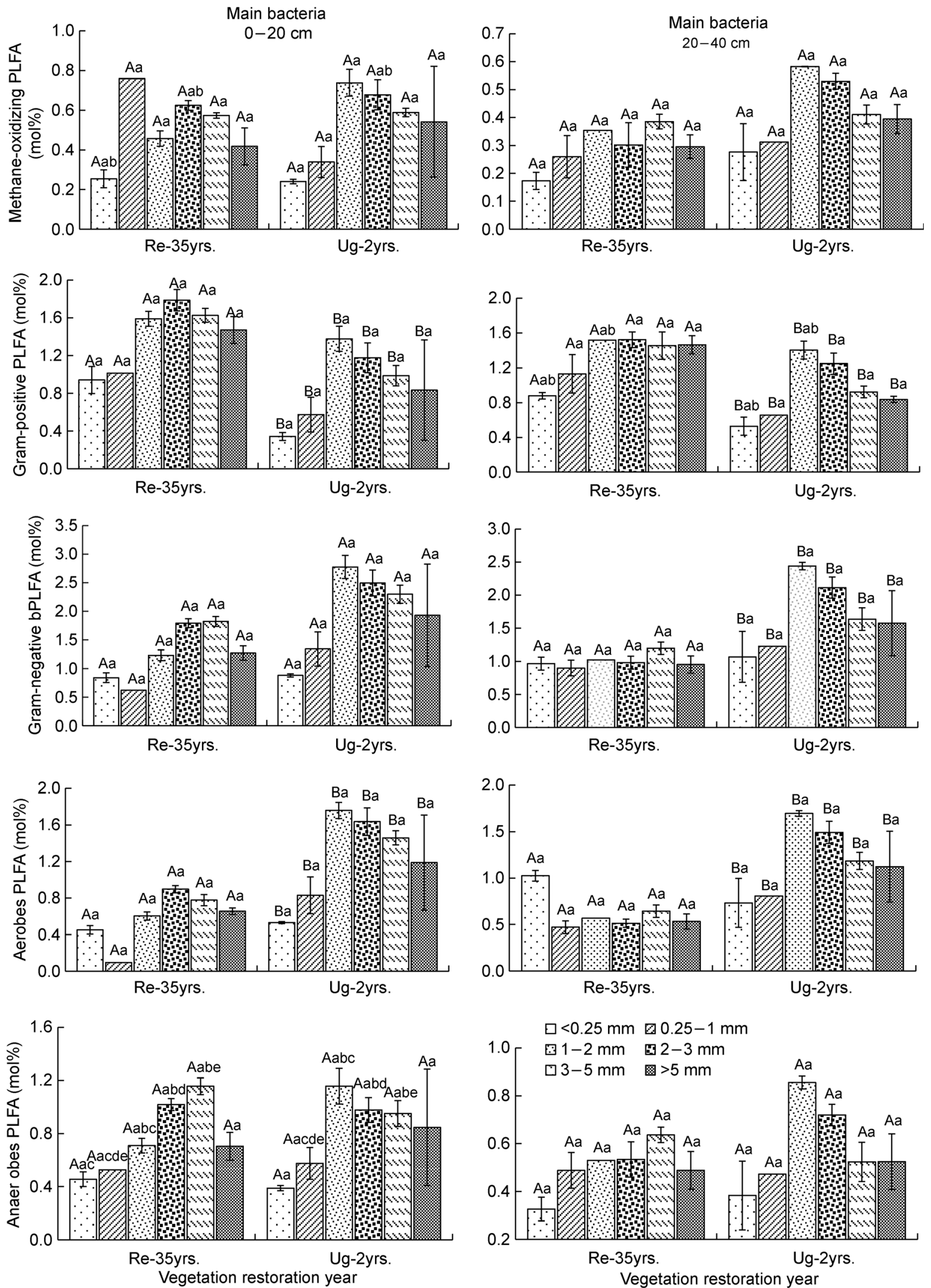

Fig. 9 The distribution characteristics of main bacteria in different soil aggregates. 
Table 3 The distribution characteristics of main physiological indicators in different soil aggregates.

\begin{tabular}{|c|c|c|c|c|c|}
\hline \multirow[t]{2}{*}{ Community } & \multirow[t]{2}{*}{ Soil aggregate size } & \multicolumn{2}{|l|}{$\mathrm{G}^{+} / \mathrm{G}^{-}$} & \multicolumn{2}{|l|}{$\mathrm{F} / \mathrm{B}$} \\
\hline & & $0-20 \mathrm{~cm}$ & $20-40 \mathrm{~cm}$ & $0-20 \mathrm{~cm}$ & $20-40 \mathrm{~cm}$ \\
\hline \multirow[t]{6}{*}{ Th.M } & $<0.25 \mathrm{~mm}$ & $1.12 \pm 0.38$ & $0.91 \pm 0.31 \mathrm{Aa}$ & $0.24 \pm 011 \mathrm{Aa}$ & $0.17 \pm 0.02 \mathrm{Aa}$ \\
\hline & $0.25-1 \mathrm{~mm}$ & $1.63 \pm 0.82$ & $1.26 \pm 0.44 \mathrm{Aa}$ & $0.18 \pm 0.02 \mathrm{Aa}$ & $0.23 \pm 0.14 \mathrm{Aa}$ \\
\hline & $1-2 \mathrm{~mm}$ & $1.29 \pm 0.66$ & $1.48 \pm 0.50 \mathrm{Aab}$ & $0.18 \pm 0.01 \mathrm{Aa}$ & $0.17 \pm 0.03 \mathrm{Aa}$ \\
\hline & $2-3 \mathrm{~mm}$ & $1.00 \pm 0.40$ & $1.55 \pm 0.41 \mathrm{Aa}$ & $0.13 \pm 0.05 \mathrm{Aa}$ & $0.15 \pm 0.04 \mathrm{Aa}$ \\
\hline & $3-5 \mathrm{~mm}$ & $0.89 \pm 0.28$ & $1.22 \pm 0.73 \mathrm{Aa}$ & $0.11 \pm 0.06 \mathrm{Aa}$ & $0.18 \pm 0.01 \mathrm{Aa}$ \\
\hline & $>5 \mathrm{~mm}$ & $1.16 \pm 0.65$ & $1.54 \pm 0.33 \mathrm{Aa}$ & $0.17 \pm 0.07 \mathrm{Aa}$ & $0.15 \pm 0.01 \mathrm{Aa}$ \\
\hline Mean & & 1.18 & 1.33 & 0.17 & 0.17 \\
\hline \multirow[t]{6}{*}{ No.G } & $<0.25 \mathrm{~mm}$ & $0.39 \pm 0.12$ & $0.50 \pm 0.12 \mathrm{Aa}$ & $0.25 \pm 0.09 \mathrm{Aa}$ & $0.16 \pm 0.07 \mathrm{Aa}$ \\
\hline & $0.25-1 \mathrm{~mm}$ & $0.43 \pm 0.22$ & $0.53 \pm 0.21 \mathrm{Aa}$ & $0.19 \pm 0.05 \mathrm{Aa}$ & $0.17 \pm 0.02 \mathrm{Aa}$ \\
\hline & $1-2 \mathrm{~mm}$ & $0.50 \pm 0.14$ & $0.57 \pm 0.18 \mathrm{Aa}$ & $0.18 \pm 0.06 \mathrm{Aa}$ & $0.14 \pm 0.01 \mathrm{Aa}$ \\
\hline & $2-3 \mathrm{~mm}$ & $0.47 \pm 0.23$ & $0.59 \pm 0.17 \mathrm{Aa}$ & $0.16 \pm 0.07 \mathrm{Aa}$ & $0.12 \pm 0.03 \mathrm{Aa}$ \\
\hline & 3-5 mm & $0.43 \pm 0.10$ & $0.56 \pm 0.22 \mathrm{Aa}$ & $0.15 \pm 0.23 \mathrm{Aa}$ & $0.10 \pm 0.04 \mathrm{Aa}$ \\
\hline & $>5 \mathrm{~mm}$ & $0.43 \pm 0.11$ & $0.53 \pm 0.31 \mathrm{Aa}$ & $0.17 \pm 0.011 \mathrm{Aa}$ & $0.12 \pm 0.06 \mathrm{Aa}$ \\
\hline Mean & & 0.44 & 0.55 & 0.18 & 0.13 \\
\hline \multirow[t]{2}{*}{ Community } & Soil aggregate size & cy/pre & & $\mathrm{S} / \mathrm{M}$ & \\
\hline & & $0-20 \mathrm{~cm}$ & $20-40 \mathrm{~cm}$ & $0-20 \mathrm{~cm}$ & $20-40 \mathrm{~cm}$ \\
\hline \multirow[t]{6}{*}{ Th.M } & $<0.25 \mathrm{~mm}$ & $0.50 \pm 0.11$ & $0.27 \pm 0.12 \mathrm{Aa}$ & $0.94 \pm 0.41 \mathrm{Aa}$ & $0.86 \pm 0.21 \mathrm{Aa}$ \\
\hline & $0.25-1 \mathrm{~mm}$ & $0.44 \pm 0.09$ & $0.77 \pm 0.12 \mathrm{Aa}$ & $0.70 \pm 0.29 \mathrm{Aa}$ & $0.99 \pm 0.14 \mathrm{Aa}$ \\
\hline & $1-2 \mathrm{~mm}$ & $0.54 \pm 0.07$ & $0.68 \pm 0.31 \mathrm{Aa}$ & $0.69 \pm 0.36 \mathrm{Aa}$ & $1.01 \pm 0.65 \mathrm{Aa}$ \\
\hline & $2-3 \mathrm{~mm}$ & $0.67 \pm 0.34$ & $0.75 \pm 0.22 \mathrm{Aa}$ & $0.68 \pm 0.16 \mathrm{Aa}$ & $0.81 \pm 0.41 \mathrm{Aa}$ \\
\hline & $3-5 \mathrm{~mm}$ & $0.42 \pm 0.26$ & $0.72 \pm 0.34 \mathrm{Aa}$ & $0.91 \pm 0.32 \mathrm{Aa}$ & $0.88 \pm 0.19 \mathrm{Aa}$ \\
\hline & $>5 \mathrm{~mm}$ & $0.66 \pm 0.41$ & $0.74 \pm 0.36 \mathrm{Aa}$ & $0.88 \pm 0.12 \mathrm{Aa}$ & $0.94 \pm 0.28 \mathrm{Aa}$ \\
\hline Mean & & 0.54 & 0.65 & 0.80 & 0.92 \\
\hline \multirow[t]{6}{*}{ No.G } & $<0.25 \mathrm{~mm}$ & $0.71 \pm 0.41 \mathrm{Aa}$ & $1.08 \pm 0.63 \mathrm{Aa}$ & $0.51 \pm 0.22 \mathrm{Aa}$ & $0.70 \pm 0.12 \mathrm{Aa}$ \\
\hline & $0.25-1 \mathrm{~mm}$ & $0.51 \pm 0.21 \mathrm{Aa}$ & $0.77 \pm 0.21 \mathrm{Aa}$ & $0.61 \pm 035 \mathrm{Aa}$ & $0.66 \pm 0.14 \mathrm{Aa}$ \\
\hline & $1-2 \mathrm{~mm}$ & $0.59 \pm 0.36 \mathrm{Aa}$ & $0.74 \pm 0.26 \mathrm{Aa}$ & $0.55 \pm 0.12 \mathrm{Aa}$ & $0.63 \pm 0.23 \mathrm{Aa}$ \\
\hline & $2-3 \mathrm{~mm}$ & $0.56 \pm 0.22 \mathrm{Aa}$ & $0.77 \pm 0.43 \mathrm{Aa}$ & $0.57 \pm 0.36 \mathrm{Aa}$ & $0.65 \pm 0.36 \mathrm{Aa}$ \\
\hline & $3-5 \mathrm{~mm}$ & $0.58 \pm 0.17 \mathrm{Aa}$ & $0.81 \pm 0.29 A a$ & $0.55 \pm 0.08 \mathrm{Aa}$ & $0.67 \pm 0.24 \mathrm{Aa}$ \\
\hline & $>5 \mathrm{~mm}$ & $0.56 \pm 0.23 \mathrm{Aa}$ & $0.77 \pm 0.31 \mathrm{Aa}$ & $0.54 \pm 0.06 \mathrm{Aa}$ & $0.67 \pm 0.34 \mathrm{Aa}$ \\
\hline Mean & & 0.59 & 0.82 & 0.55 & 0.66 \\
\hline
\end{tabular}

Note: $\mathrm{G}^{+} / \mathrm{G}^{-}$: Gram-positive bacteria/Gram-negative bacteria. F/B: Fungi/Bacteria. cy/pre: cyclopropyl(cy17:0 + cy19:0)/precursors(16:1 $1 \omega 7+$

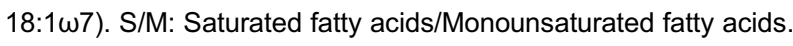

\section{Discussion}

4.1 Impacts of vegetation restoration on soil microorganism group

Soil microbial structural diversity is affected by a variety of factors, such as land uses, farming history and vegetation types. Ug-2yrs had a lower total PLFA, whose concentration was approximately one-tenth that of Re-35yrs. However, the bacterial PLFA proportions of Ug-2yrs were much higher than those of Re-35yrs, with actinomycetes and fungi proportions being lower than the bacterial proportions and with protozoa having the lowest proportions in those samples. A history of overgrazing is the main reason that led to Ug-2yrs having 

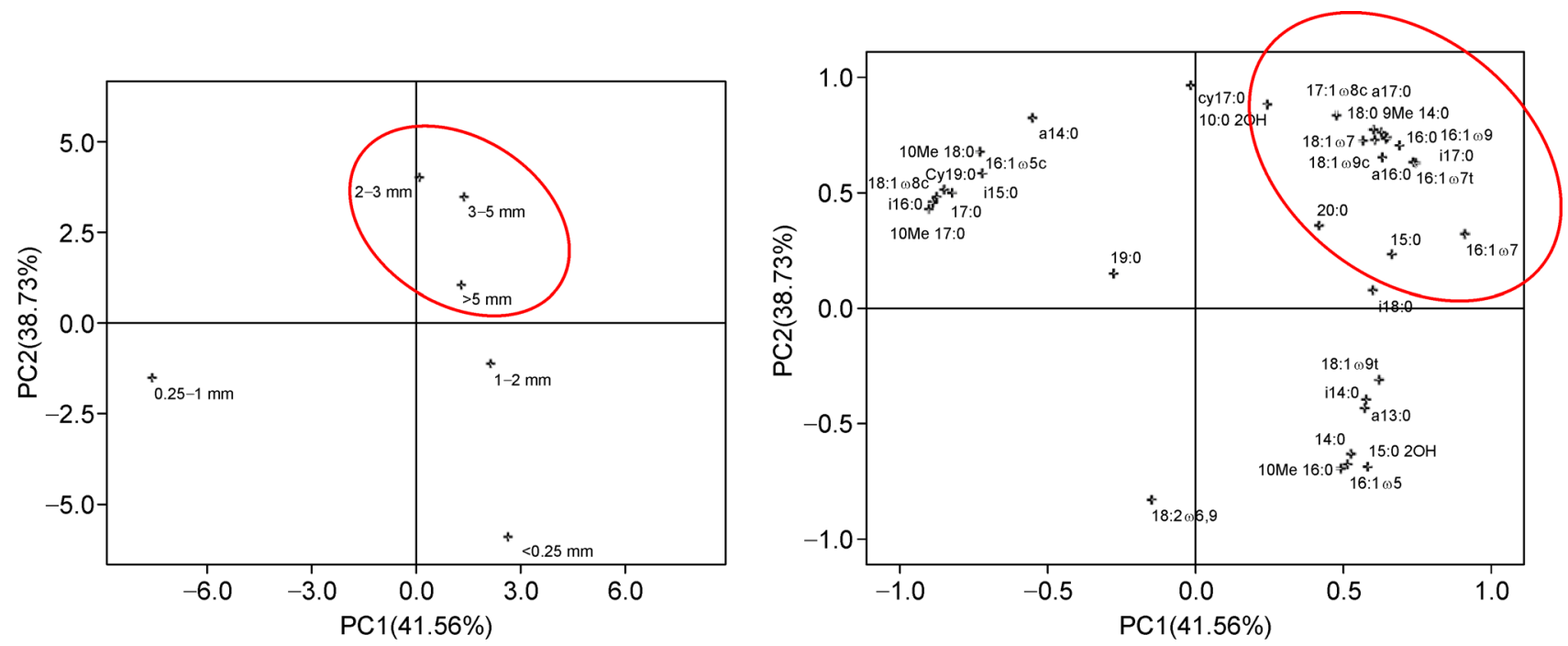

$0-20 \mathrm{~mm}$
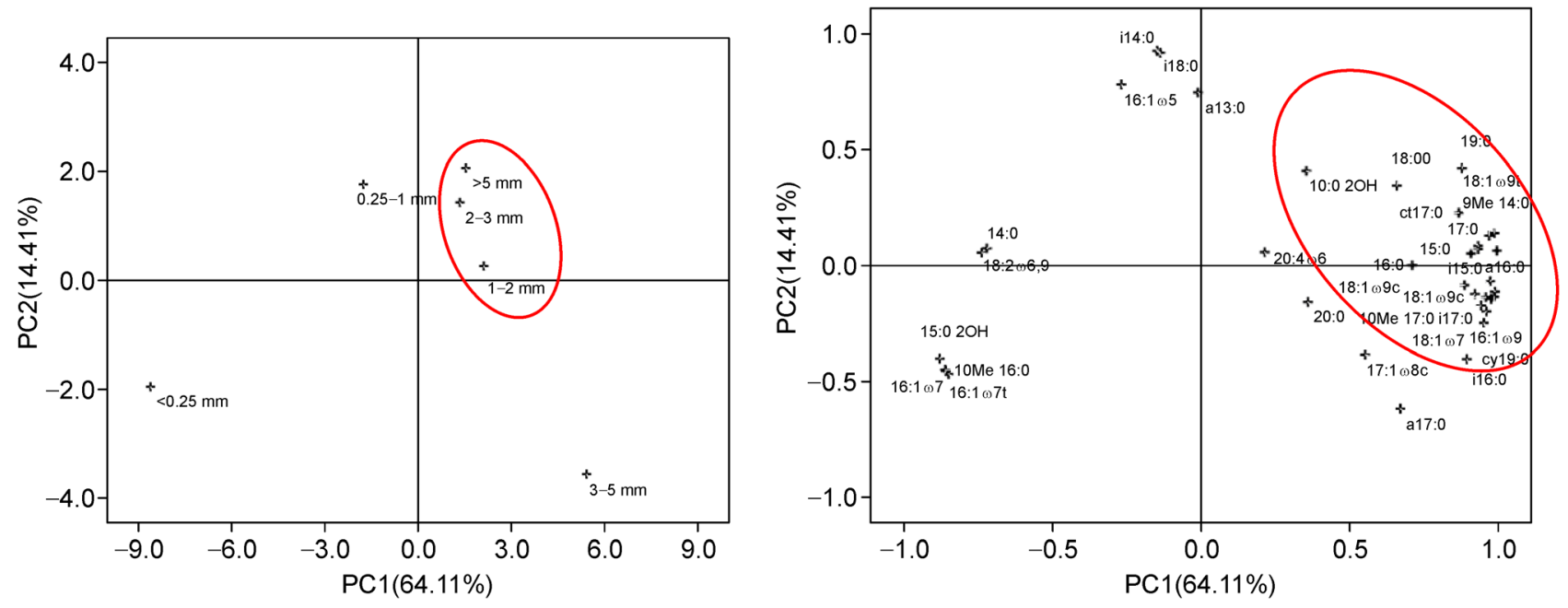

20-40 mm

Fig. 10 Principal component analysis (PCA) of PLFA in Thymus mongolicuse community soil.

lower soil microbial diversity. Vegetation restoration cannot be effective with short-term grazing. Lower plant biomass results in less transformation of plant carbon to soil carbon. If a carbon source cannot replenish the soil to meet the requirements of its microorganisms, the soil microbial diversity balance will be disrupted (Briar et al., 2011; Zhang et al., 2016). Compared with Re-35yrs, the following species of

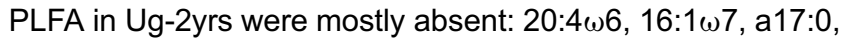
i18:0, 17:0, 17:1 $\omega 8 \mathrm{c}$, etc. In other words, although the number of bacteria in Ug-2yrs was greater, there were fewer species than in Re-35yrs, and there were no protozoa in Ug-2yrs. The ratio of fungi to bacteria $(F / B)$ is used to estimate the relative energy utilization of fungi and bacteria. Bacterial energy utilization is characterized by rapid utilization, taking advantage of residue or substrate, and has a higher turnover rate (Six et al., 2006; Briar et al., 2011; Daynes et al., 2012; Waring et al., 2013). Moreover, the F/B ratio also reflects the quality of the organic matter in a soil system. The $F / B$ ratio is an important indicator in evaluating the control ability and buffering capacity of an ecosystem. High F/B values suggest a superior soil organic matter condition. In Re-35yrs, with a high level of soil organic carbon concentration, fungi formed the major microbial group attending to plant residue decomposition. Fungi are the main agents of organic matter decomposition, and the fungal community affects the rate of decomposition and C cycling (Mäkipää et al., 2017). In Re35yrs, the soil microbial community has already shifted from bacteria groups to fungal groups. The energy utilization has also changed from a high level turnover rate (bacteria) to a fixed energy consumption (fungi). However, in Ug-2yrs, the energy utilization of the soil microbial community remained in a bacterial growth stage, with high speed decomposition and transformation.

In Re-35yrs, there are two main characteristics of the soil microbial diversity. First, although total PLFA in Re-35yrs was higher than in Ug-2yrs, the bacterial proportion was lower, and 

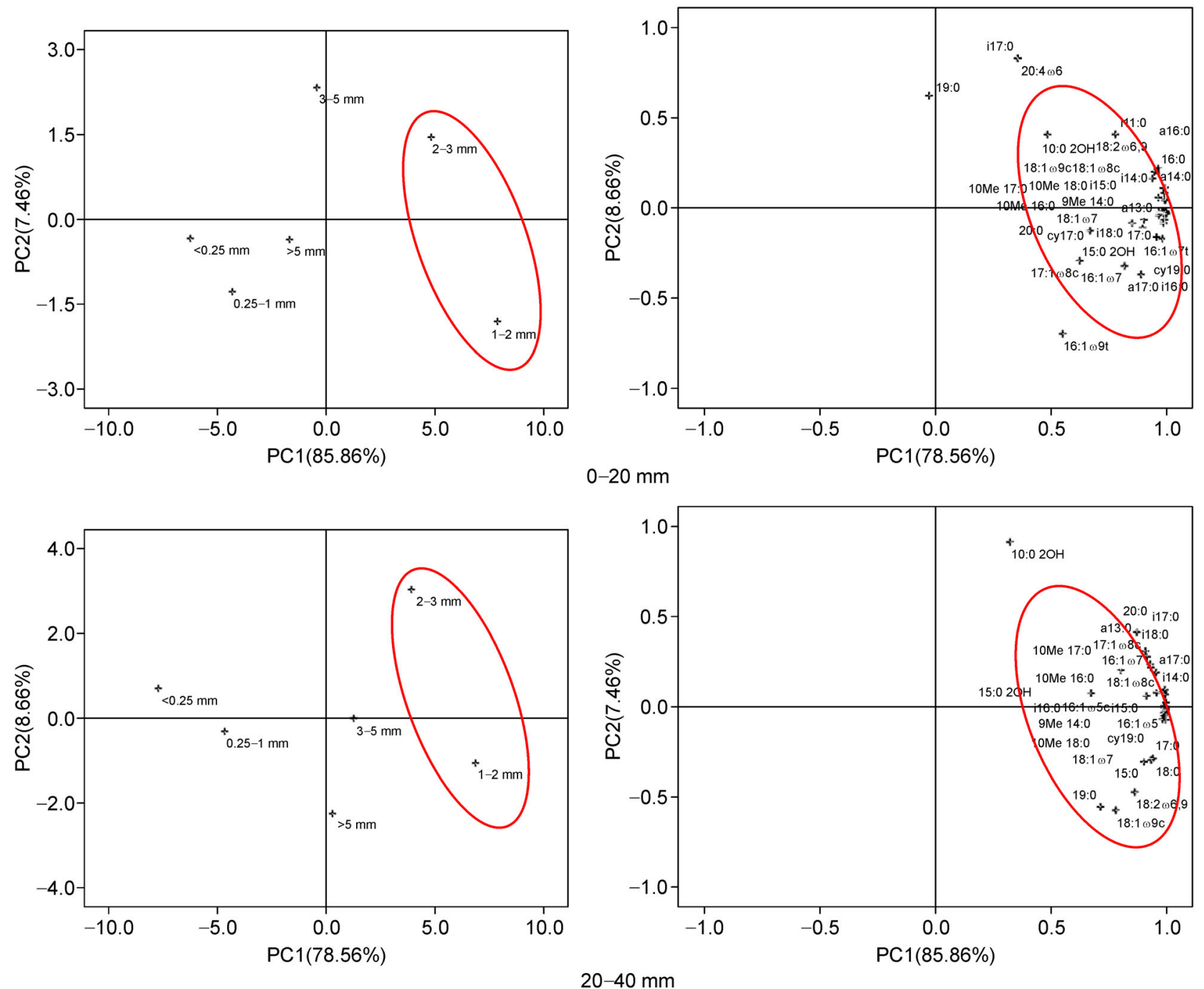

Fig. 11 Principal component analysis (PCA) of PLFA in nongrazing grassland soil.

Table 4 General score in different soil aggregate.

\begin{tabular}{llcccccc}
\hline Communities & Soil layer $(\mathrm{cm})$ & \multicolumn{5}{c}{ General score } \\
\cline { 3 - 7 } & & $<0.25 \mathrm{~mm}$ & $0.25-1 \mathrm{~mm}$ & $1-2 \mathrm{~mm}$ & $2-3 \mathrm{~mm}$ & $3-5 \mathrm{~mm}$ & $>5 \mathrm{~mm}$ \\
\hline Thymus mongolicus & $0-20$ & -0.95 & -3.76 & 0.07 & 1.78 & 2.00 & 0.85 \\
& $20-40$ & -5.75 & -1.07 & 0.95 & 1.36 & 3.03 & 1.48 \\
Nongrazing & $0-20$ & -5.90 & -3.68 & 5.45 & 3.28 & 0.97 & -0.09 \\
& $20-40$ & -5.44 & -3.76 & 6.61 & 4.25 & -0.19 & -1.45 \\
\hline
\end{tabular}

unknown microorganisms accounted for a large percentage in a few of the soil aggregates, just lower than percent accounted for by bacteria. External nutrients are the primary reason for the different diversity conditions between the two communities (Trivedi et al., 2013; Chen et al., 2017). Ug-2yrs is in a transition stage of balanced mineralization and accumulation due to its short duration of restoration. Mineralized organic nutrients can only provide support to bacteria and cannot completely satisfy the growth and development of various microorganism groups (Fierer et al., 2007; Leff et al., 2015; Trivedi et al., 2017). Second, the proportion of Grampositive bacteria was higher than the proportion of Gramnegative bacteria in Re-35yrs.

This study indicated that environment adaptability influences soil physiologic indicators to varying degrees. In addition, microorganism continually changed their regulation 
of pathways as their environment changed. To adapt to the changing environment, soil microbes were forced to make physiologic adaptions in response to varying stress from their environment. For example, physiologic responses of soil microorganisms change when faced with environment stress, such as low nutrients or toxic compounds, and these responses are reflected in their chemical components (Chen et al., 2015). To determine the effects of environmental stress on microbial physiologic structure, many researchers have begun to use microbiological PLFA indicators to reflect the physiologic changes of the microbial community (Allison et al., 2005; Luo et al., 2018). Those studies found that when the bacterial growth stage changed from logarithmic growth to stable growth, precursor PLFAs were converted to PLFAs with cyclopropyl groups. This conversion implies that some source of stress was present in the environment, such as restrictions on carbon resources and oxygen. For example, when the growth stage of Gram-negative bacteria changes from exponential growth to slow static growth, soil microorganisms will convert some monoene PLFA into cyclopropyl PLFA. Thus, the ratio of cyclopropyl PLFA (cy17:0 and cy19:0) to

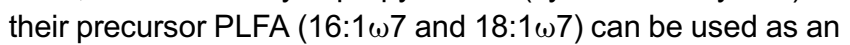
indicator of the physiologic status of a Gram-negative bacterial community.

4.2 Impacts of soil aggregates sizes on soil microorganism group

Impacts of aggregation on the soil microbiome can also depend on aggregate size, as microaggregates $(<250 \mu \mathrm{m})$ are reported to harbour relatively dynamic and diverse microbial communities, whereas microbial communities of macroaggregates $(>250 \mu \mathrm{m})$ are more stable (Upton et al., 2019). The ratio of $\mathrm{G}^{+} / \mathrm{G}^{-}$in $\mathrm{Re}-35 y \mathrm{rs}$ was two times greater than that in $\mathrm{Ug}-2 \mathrm{yrs}$. $\mathrm{G}^{+} / \mathrm{G}^{-}$is the ratio of Gram-positive to Gram-negative bacteria. An increasing $\mathrm{G}^{+} / \mathrm{G}^{-}$ration suggests a transformation of Gram-negative bacteria groups to Grampositive groups. As carbon sources are reduced, the soil chemotroph community (mostly containing gram-negative bacteria) turns into a chemotroph-heterotroph community or from a nutrient-abundant to a nutrient-deficient condition (Richardson et al., 2011; Mackay et al., 2017). Some studies have indicated that differences in microbial diversity are mainly reflected in Gram-negative bacteria and protozoa and are caused by different vegetation and land use and by differences in the living environment and various stresses (Zhang et al., 2017). Long-term vegetation restoration in Re$35 y$ rs is conducive to improved soil structure and texture. The improvement in the soil environment provides the necessary conditions for the restoration of microbial diversity. However, the transformation of the community from nutrient-rich to heterotroph-dominated leads to a reduction in soil microbial, especially in small aggregates (Sarker et al., 2018). This observation is consistent with our results. In Re-35yrs, total PLFA increased as soil aggregate size increased. However, in the nongrazing community, the trend followed a normal distribution, with highest levels of PLFA in the 1-2 $\mathrm{mm}$ and

\section{2-3 $\mathrm{mm}$ aggregates.}

The cyc/prec value is the ratio of cyclopropyl PLFAs to their precursors. This ratio represent the stress level (including carbon source and oxygen limitation) of microorganisms in the soil system (Trivedi et al., 2015). Generally, the values of cyc/ prec in 2-3 $\mathrm{mm}$ and 3-5 $\mathrm{mm}$ aggregates were lower than those in $<0.25 \mathrm{~mm}, 0.25-1 \mathrm{~mm}, 1-2 \mathrm{~mm}$ and $>5 \mathrm{~mm}$ aggregates, and the values from 0 to $20 \mathrm{~cm}$ samples were lower than those from 20 to $40 \mathrm{~cm}$. This result indicates that microorganisms suffered significantly less stress in large aggregates than in small aggregates. There are also likely advantages of localizaton at the aggregate exterior, such as greater access to carbon and nutrient flow from the bulk soil. Furthermore, factors such as aggregate size may influence microbial community composition and activity (Schlüter et al., 2018; Upton et al., 2019). In Re-35yrs, the most abundant microbial diversity was found in the 3-5 $\mathrm{mm}$ aggregates, followed by that in the 2-3 $\mathrm{mm}$ aggregates. However, in the nongrazing community, a similar level of diversity was found in 1-2 mm and 2-3 $\mathrm{mm}$ aggregates. With increasing years of vegetation restoration, soil aggregate stability is gradually enhanced. Soil microbial communities begin to select stable aggregates in which to live, as is consistent with a response to low nutrients (Bonanomi et al., 2017). The S/M ratio refers to the ratio of saturated fatty acids to monounsaturated fatty acids. This ratio reflects the response to low nutrients and is also an indicator of microbial nutritional effectiveness. A value of S/M greater than 1 indicates that the soil has a high concentration of organic carbon and that there has been organic carbon input (Bell et al., 2015; Zeng et al., 2015; Chen et al., 2017). Because mega-aggregates and macro-aggregates generally contain more labile substrates principally derived from plant residues and exhibit higher fungal biomass than microaggregates (Jiang et al., 2017), these observation support our hypothesis that aggregate-related changes in soil microbial communities improve soil aggregate stability. As the results show, the S/M ratios in Re-35yrs were higher than in Ug-2yrs, with the exception of 1-2 $\mathrm{mm}$ aggregates from the $20-40 \mathrm{~cm}$ soil layer $(\mathrm{S} / \mathrm{M}=1.001)$. The other values for the $\mathrm{S} /$ $\mathrm{M}$ ratio fell between 0.988 and 0.677 and $0.507-0.699$. Years of vegetation restoration provides adequate nutrition, leading to lower nutrient stress among soil microorganisms in $\mathrm{Re}-$ 35yrs compared to those in Ug-2yrs.

\section{Conclusions}

After years of natural restoration, the biological and structural diversity in Re-35yrs was significantly greater than that in Ug2yrs. In different plant communities, the stress of soil microorganisms in aggregates of large particle size was significantly lower than in aggregates of small particles, especially in the $2-3 \mathrm{~mm}$ and $3-5 \mathrm{~mm}$ aggregates. Natural restoration has a positve effect on soil microbial diversity was generally higher in large particle size aggregates, which leads to low environmental stress and strong stability. This new insight into interactions at the soil structure/biology interface 
leads to addressing further related questions such as how soil aggregation may impact microbial community composition and longer-term adaptations in response to environmental pressures.

\section{Acknowledgements}

This study was supported by the National Natural Sciences Foundation of China (41807060, 41977061), National Special Research and Development Project during the Thirty Five-year Plan Period (2017YFC0504702).

\section{References}

Allison, V.J., Miller R.M., Jastrow, J.D., Matamala, R., Zak, D.R., 2005 Changes in soil microbial community structure in a tallgrass prairie chronosequence. Soil Science Society of America Journal 69, 1412-1421.

An, S.S., Cheng, Y., Huang, Y.M., Liu, D., 2013. Effects of revegetation on soil microbial biomass, enzyme activities, and nutrient cycling on the Loess Plateau in China. Restoration Ecology 5, 600-607.

Bardgett, R.D., McAlister, E., 1999. The measurement of soil fungal: bacterial biomass ratios as an indicator of ecosystem selfregulation in temperate meadow grasslands. Biology and Fertility of Soils 29, 282-290.

Bell, C.W., Asao, S., Calderon, F., Wolk, B., Wallenstein, M.D., 2015. Plant nitrogen uptake drives rhizosphere bacterial community assembly during plant growth. Soil Biology \& Biochemistry 85, 170-182.

Bonanomi, G., Cesarano, G., Lombardi, N., Motti, R., Scala, F., Mazzoleni, S., Incerti, G., 2017. Litter chemistry explains contrasting feeding preferences of bacteria, fungi, and higher plants. Scientific Reports 7, 9208.

Bossio, D.A., Scow, K.M., Gunapala, N., Graham, K.J., 1998. Determination of soil microbial communities: effects of agricultural management, season, and soil type on phospholipids fatty acid profiles. Microbial Ecology 36, 1-12.

Briar, S.S., Fonte, S.J., Park, I., Six, J., Scow, K., Ferris, H., 2011. The distribution of nematodes and soil microbial communities across soil aggregate fractionsand farm management systems. Soil Biology \& Biochemistry 43, 905-914.

Cao, C.Y., Zhang, Y., Qian, W., Liang, C., Wang, C., Tao, S., 2017. Land-use changes influence soil bacterial communities in a meadow grassland in Northeast China. Solid Earth 8, 1119-1129.

Carrasco, L., Gattinger, A., Fliessbach, A., Roldán, A., Schloter, M., Caravaca, F., 2010. Estimation by PLFA of microbial community structure associated with the rhizosphere of Lygeum spartum and Piptatherum miliaceum growing in semiarid mine tailings. Microbial Ecology 60, 265-271.

Chen, X., Li, Z., Liu, M., Jiang, C., Che, Y., 2015. Microbial community and functional diversity associated with different aggregate fractions of a paddy soil fertilized with organic manure and/or NPK fertilizer for 20 years. Journal of Soils and Sediments 15 292-301.

Chen, Y.L., Xu, T., Veresoglou, S.D., Hu, H.W., Hao, Z.P., Hu, Y.J., Liu,
L., Deng, Y., Rillig, M.C., Chen, B.D., 2017. Plant diversity represents the prevalent determinant of soil fungal community structure across temperate grasslands in northern China. Soil Biology \& Biochemistry 110, 12-21.

Daynes, C.N., Zhang, N., Saleeba, J.A., McGee, P.A., 2012. Soil aggregates formed in vitro by saprotrophic Trichocomaceae have transient water-stability. Soil Biology \& Biochemistry 48, 151-161.

Deng, L., Kim, D.G., Peng, C.H., Shangguan, Z., 2018. Controls of soil and aggregate associated organic carbon variations following natural vegetation restoration on the Loess Plateau in China. Land Degradation \& Development 29, 3974-3984.

Deng, L., Shangguan, Z.P., 2017. Afforestation drives soil carbon and nitrogen changes in China. Land Degradation \& Development 28, 151-165.

Deng, L., Zhang, Z., Shangguan, Z., 2014. Long-term fencing effects on plant diversity and soil properties in China. Soil \& Tillage Research 137, 7-15.

Fanin, N., Moorhead, D., Bertrand, I., 2016. Eco-enzymatic stoichiometry and enzymatic vectors reveal differential C, N, P dynamics in decaying litter along a land-use gradient. Biogeochemistry 129, 21-36.

Federle, T.W., Dobbins, D.C., Thorton-Manning, J.R., Jones, D.D., 1986. Microbial biomass, activity, and community structure in subsurface soils. Ground Water 24, 365-374.

Fierer, N., Bradford, M.A., Jackson, R.B., 2007. Toward an ecological classification of soil bacteria. Ecology 88, 1354-1364.

Frostegård, A., Bååth, E., 1996. The use of phospholipid fatty acid analysis to estimate bacterial and fungal biomass in soil. Biology and Fertility of Soils 22, 59-65.

Frostegård, A., Tunlid, A., Bååth, E., 1993. Phospholipid Fatty Acid composition, biomass, and activity of microbial communities from two soil types experimentally exposed to different heavy metals. Applied and Environmental Microbiology 59, 3605-3617.

Guo, Y.Q., Hou, L.J., Zhang, Z.Y., Zhang, J., Cheng, J., Wei, G., Lin, Y., 2019. Soil microbial diversity during 30 years of grassland restoration on the Loess Plateau China: Tight linkages with plant diversity. Research Article 30, 1172-1182.

Herrera, P.S., Lebeis, S.L., Bailey, J.K., 2016. Giving back to the community: microbial mechanisms of plant-soil interactions. Functional Ecology 30, 1043-1052.

Janine, B.R., Jasmin, J., Bernhard, S., Helmut, B., Teri, B., 2005. Soil feedbacks of plant diversity on soil microbial communities and subsequent plant growth. Perspectives in Plant Ecology, Evolution and Systematics 7, 27-49.

Jiang, Y., Liu, M., Zhang, J., Chen, Y., Chen, X., Chen, L., Li, H., Zhang, X.X., Sun, B., 2017. Nematode grazing promotes bacterial community dynamics in soil at the aggregate level. ISME Journal 11, 2705-2717.

Kieft, T.L., Wilch, E., O'connor, K., Ringelberg, D.B., White, D.C., 1997. Survival and phospholipid fatty acid profiles of surface and subsurface bacteria in natural sediment microcosms. Applied and Environmental Microbiology 63, 1531-1542.

Kroppenstedt, R., 1985. Fatty acid and menaquinone analysis of actinomycetes and related organisms. In: Goodfellow, M., Minnikin, D., eds. Chemicalmethods in Bacterial Systematics, London: Academic Press, pp. 173-199. 
Leff, J.W., Jones, S.E., Prober, S.M., Barberán, A., Borer, E.T., Firn, J. L., Harpole, W.S., Hobbie, S.E., Hofmockel, K.S., Knops, J.M.H., McCulley, R.L., La Pierre, K., Risch, A.C., Seabloom, E.W., Schütz, M., Steenbock, C., Stevens, C.J., Fierer, N., 2015. Consistent responses of soil microbial communities to elevated nutrient inputs in grasslands across the globe. Proceedings of the National Academy of Sciences of the United States of America 112, 10967-10972.

Lenka, N.K., Dass, A., Sudhishri, S., Patnaik, U.S., 2012. Soil carbon sequestration and erosion control potential of hedgerows and grass filter strips in sloping agricultural lands of eastern India. Agriculture, Ecosystems \& Environment 158, 31-40.

Li, C., Fultz, L.M., Moore-Kucera, J., Acosta-Martínez, V., Kakarla, M., Weindorf, D.C., 2018. Soil microbial community restoration in Conservation Reserve Program semi-arid grasslands. Soil Biology \& Biochemistry 118, 166-177.

Liao, H., Zhang, Y., Zuo, Q., Du, B., Chen, W., Wei, D., Huang, Q., 2018. Contrasting responses of bacterial and fungal communities to aggregate-size fractions and long-term fertilizations in soils of northeastern China. Science of the Total Environment 635, 784 792.

Liu J., Jia X. Y., Yan W. M., Zhong Y.Q., Shangguan Z.P., 2020a. Changes in soil microbial community structure during long-term secondary succession. Land Degradation \& Development

Liu, J., Li, S., Ouyang, Z., Tam, C., Chen, X., 2008. Ecological and socioeconomic effects of China's policies for ecosystem services. Proceedings of the National Academy of Sciences of the United States of America 105, 9477-9482.

Liu, J.J., Zheng, Y.M., Yan, J.X., 2013. Succession of plant and soil microbial communities with restoration of abandoned land in the Loess Plateau, China. Journal of Soils and Sediments 13, 760769.

Liu, Y.L., Zhu, G.Y., Hai X.Y., Li, J.W., Shangguan Z.P., Peng C.H., Deng L., 2020b. Long-term forest succession improves plant diversity and soil quality but not significantly increase soil microbial diversity: evidence from the Loess Plateau. Ecological Engineering 142, 105431.

Luo, S.S., Wang, S.J., Tian, L., Shi, S., Xu, S., Yang, F., Li, X., Wang, Z., Tian, C., 2018. Aggregate-related changes in soil microbial communities under different ameliorant applicaitons in salinesodic soils. Geoderma 329, 108-117.

Mackay, J.E., Macdonald, L.M., Smernik, R.J., Cavagnaro, T.R., 2017. Organic amendments as phosphorus fertilisers: chemical analyses, biological processes and plant $\mathrm{P}$ uptake. Soil Biology \& Biochemistry 107, 50-59.

Mäkipää, R., Rajala, T., Schigel, D., Rinne, K.T., Pennanen, T., Abrego, N., Ovaskainen, O., 2017. Interactions between soil- and dead wood-inhabiting fungal communities during the decay of Norway spruce logs. ISME Journal 11, 1964-1974.

Muruganandam, S., Israel, D.W., Robarge, W.P., 2010. Nitrogen transformations and microbial communities in soil aggregates from three tillage systems. Soil Science Society of America Journal 74, 120-129.

O'Leary, M.H., 1988. Carbon isotopes in photosynthesis. Bioscience 38, 328-336.

Pollierer, M.M., Ferlian, O., Scheu, S., 2015. Temporal dynamics and variation with forest type of phospholipid factty acids in litter and soil of temperate forests across regions. Soil Biology \& Biochemistry $91,248-257$.

Ranjard, L., Richaume, A., 2001. Quantitative and qualitative microscale distribution of bacteria in soil. Research in Microbiology 152, 707-716.

Richardson, A.E., Lynch, J.P., Ryan, P.R., Delhaize, E., Smith, F.A., Smith, S.E., Harvey, P.R., Ryan, M.H., Veneklaas, E.J., Lambers, H., Oberson, A., Culvenor, R.A., Simpson, R.J., 2011. Plant and microbial strategies to improve the phosphorus efficiency of agriculture. Plant and Soil 349, 121-156.

Ringelberg, D.B., Stair, J.O., Almeida, J., Norby, R.J., O'Neill, E.G., White, D.C., 1997. Consequences of rising atmospheric carbon dioxide levels for the belowground microbiota associated with white oak. Journal of Environmental Quality 26, 495-503.

Sarker, T.C., Incerti, G., Spaccini, R., Piccolo, A., Mazzoleni, S., Bonanomi, G., 2018. Linking organic matter chemistry with soil aggregate stability: insight from ${ }^{13} \mathrm{C}$ NMR spectroscopy. Soil Biology \& Biochemistry 117, 175-184.

Schlüter S., Henjes S., Zawallich J., Bergaust, L., Horn, M., Lppisch, O., Vogel, H., Dorsch, P, 2018. Denitrification in soil aggregate analogues-effect of aggregate size and oxygen diffusion. Frontiers in Environmental Science 6, 17.

Shi, X., Yu, D., Xu, S., Warner, E.D., Wang, H.J., Sun, W.X., Zhao, Y. C., Gong, Z.T., 2010. Cross-reference for relating genetic soil classification of China with WRB at different scales. Geoderma 155, 344-350.

Six, J., Elliott, E.T., Paustian, K., 2000. Soil macroaggregate turnover and microaggregate formation: a mechanism for $\mathrm{C}$ sequestration under no-tillage agriculture. Soil Biology \& Biochemistry 32, 2099 2103.

Six, J., Frey, S.D., Thiet, R.K., Batten, K.M., 2006. Bacterial and fungal contributions to carbon sequestration in agroecosystems. Soil Science Society of America Journal 70, 555-569.

Smith, A.P., Marín-Spiotta, E., Graaff, M A D., Balser, T.C., 2014. Microbial community structure varies across soil organic matter aggregate pools during tropical land cover change. Soil Biology \& Biochemistry 77, 292-303.

Soil Survey Staff, 2010. Keys to Soil Taxonomy, U.S. Department of Agriculture11th ed. NRCS.

Trivedi, P., Anderson, I.C., Singh, B.K., 2013. Microbial modulators of soil carbon storage: integrating genomic and metabolic knowledge for global prediction. Trends in Microbiology 21, 641-651.

Trivedi, P., Delgado-Baquerizo, M., Jeffries, T.C., Trivedi, C., Anderson, I.C., Lai, K., McNee, M., Flower, K., Pal Singh, B., Minkey, D., Singh, B.K., 2017. Soil aggregation and associated microbial communities modify the impact of agricultural management on carbon content. Environmental Microbiology 19, 30703086.

Trivedi, P., Rochester, I.J., Trivedi, C., Van Nostrand, J.D., Zhou, J., Karunaratne, S., Anderson, I.C., Singh, B.K., 2015. Soil aggregate size mediates the impacts of cropping regimes on soil carbon and microbial communities. Soil Biology \& Biochemistry 91, 169-181.

Upton, R.N., Bach, E.M., Hofmockel, K.S., 2019. Spatio-temporal microbial community dynamics within soil aggregates. Soil Biology \& Biochemistry 132, 58-68. 
Vos, M., Wolf, A.B., Jennings, S.J., Kowalchuk, G.A., 2013. Microscale determinants of bacterial diversity in soil. FEMS Microbiology Reviews 37, 936-954.

Walker, L.R., Walker, J., Hobbs, R.J., 2007. Linking Restoration and Ecological Succession. Berlin: Springer

Wang, K., Zhang, Y., Tang, Z., Shangguan, Z., Chang, F., Jia, F., Chen, Y., He, X., Shi, W., Deng, L., 2019. Effects of grassland afforestation on structure and function of soil bacterial and fungal communities. Science of the Total Environment 676, 396-406.

Waring, B.G., Averill, C., Hawkes, C.V., 2013. Differences in fungal and bacterial physiology alter soil carbon and nitrogen cycling: insights from meta-analysis and theoretical models. Ecology Letters 16, 887-894.

Wilkinson, S.C., 1988. Gram-negative Bacteria. In: Ratledge, C., Wilkinson, S.C., eds. Microbial Lipids, vol 1. London: Academic Press, pp. 299-488.

Xiao, L., Yao, K.H., Li, P., Liu, Y., Chang, E., Zhang, Y., Zhu, T., 2020. Increased soil aggregate stability is strongly correlated with root and soil properties along a gradient of secondary succession on the Loess Plateau. Ecological Engineering 143, 105671.

Yan, Y., Dai, Q., Hu, G., Jiao, Q., Mei, L., Fu, W., 2020. Effects of vegetation type on the microbial characteristics of the fissure soilplant systems in karst rocky desertification regions of SW China. Science of the Total Environment 712, 136543.

Zelles L. 1999. Fatty acid patterns of phospholipids and lipopolysaccharides in the characterisation of microbial communities in soil: a review. Biology and Fertility of Soils 29, 111-129

Zelles, L., Bai, Q.Y., Rackwitz, R., Chadwick, D., Beese, F., 1995. Determination of phospholipid-and lipopolysaccharide-derived fatty acids as an estimate of microbial biomass and community structures in soils. Biology and Fertility of Soils 19, 115-123.

Zeng, J., Liu, X., Song, L., Lin, X., Zhang, H., Shen, C., Chu, H., 2015. Nitrogen fertilization directly affects soil bacterial diversity and indirectly affects bacterial community composition. Soil Biology \& Biochemistry 92, 41-49.

Zhang, Q., Liang, G., Guo, T., He, P., Wang, X., Zhou, W., 2017. Evident variations of fungal and actinobacterial cellulolytic communities associated with different humified particle-size fractions in a long-term fertilizer experiment. Soil Biology \& Biochemistry 113, 1-13.

Zhang, Q., Liang, G., Zhou, W., Sun, J., Wang, X., He, P., 2016. Fattyacid profiles and enzyme activities in soil particle-size fractions under long-term fertilization. Soil Science Society of America Journal 80, 97-111.

Zhao, C., Long, J., Liao, H., Zheng, C., Li, J., Liu, L., Zhang, M., 2019. Dynamics of soil microbial communities following vegetation succession in a karst mountain ecosystem, Southwest China. Southwest China. 9, 2160.

Zhao, F.Z., Bai, L., Wang, J.Y., Deng, J., Ren, C.J., Han, X.H., Yang, G.H., Wang, J., 2019. Change in soil bacterial community during secondary succession depend on plant soil characteristics. Catena 173, 246-252.

Zhu, G.Y., Tang, Z.S., Shangguan, Z.P., Peng, C.H., Deng, L., 2019. Factors affecting the spatial and temporal variations in soil erodibility of China. Journal of Geophysical Research. Earth Surface 124, 737-749.

Zou, H.Y., Guan, X.Q., 1997. Approach to management path way of Yun Wushan mountain natural protecting area. Caoye Kexue 14, 1-2 (Chinese with English Abstract). 